\title{
CARINA alkalinity data in the Atlantic Ocean
}

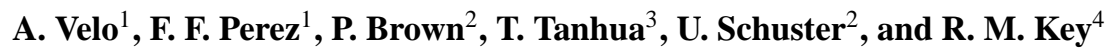 \\ ${ }^{1}$ Instituto de Investigaciones Marinas, CSIC, Eduardo Cabello, 6, 36208 Vigo, Spain \\ ${ }^{2}$ School of Environmental Sciences, University of East Anglia, Norwich, NR4 7TJ, UK \\ ${ }^{3}$ Leibniz-Institut für Meereswissenschaften, Marine Biogeochemie, Kiel, Germany \\ ${ }^{4}$ Princeton University, Program in Atmospheric and Oceanic Science, Forrestal Campus/Sayre Hall, \\ Princeton, NJ 08544, USA
}

\author{
Received: 25 June 2009 - Published in Earth Syst. Sci. Data Discuss.: 3 August 2009 \\ Revised: 13 November 2009 - Accepted: 16 November 2009 - Published: 27 November 2009
}

\begin{abstract}
Data on carbon and carbon-relevant hydrographic and hydrochemical parameters from previously non-publicly available cruise data sets in the Arctic, Atlantic and Southern Ocean have been retrieved and merged to a new database: CARINA (CARbon IN the Atlantic).

These data have gone through rigorous quality control $(\mathrm{QC})$ procedures to assure the highest possible quality and consistency. The data for most of the measured parameters in the CARINA data base were objectively examined in order to quantify systematic differences in the reported values, i.e. secondary quality control. Systematic biases found in the data have been corrected in the data products, i.e. three merged data files with measured, calculated and interpolated data for each of the three CARINA regions; Arctic, Atlantic and Southern Ocean. Out of a total of 188 cruise entries in the CARINA database, 98 were conducted in the Atlantic Ocean and of these, 75 cruises report alkalinity values.

Here we present details of the secondary QC on alkalinity for the Atlantic Ocean part of CARINA. Procedures of quality control, including crossover analysis between cruises and inversion analysis of all crossover data are briefly described. Adjustments were applied to the alkalinity values for 16 of the cruises in the Atlantic Ocean region. With these adjustments the CARINA database is consistent both internally as well as with GLODAP data, an oceanographic data set based on the World Hydrographic Program in the 1990s. Based on our analysis we estimate the internal accuracy of the CARINA-ATL alkalinity data to be $3.3 \mu \mathrm{mol} \mathrm{kg}^{-1}$. The CARINA data are now suitable for accurate assessments of, for example, oceanic carbon inventories and uptake rates and for model validation.
\end{abstract}

\section{Data coverage and parameter measured}

Repository-Reference: doi:10.3334/CDIAC/otg.CARINA.ATL.V1.0

Available at:

http://cdiac.ornl.gov/ftp/oceans/CARINA/CARINA_

Database/CARINA.ATL.V1.0/

Coverage: $60^{\circ} \mathrm{S}-75^{\circ} \mathrm{N} ; 80^{\circ} \mathrm{W}-34^{\circ} \mathrm{E}$

Location Name: Atlantic Ocean

Date/Time Start: 1977-10-7

Date/Time End: 2006-02-02

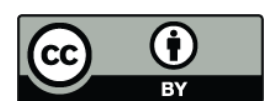

Correspondence to: A. Velo

(avelo@iim.csic.es)

Published by Copernicus Publications. 


\begin{tabular}{|c|c|c|c|c|}
\hline $\begin{array}{l}\text { Data Product } \\
\text { Parameter Name }\end{array}$ & $\begin{array}{l}\text { Data Product } \\
\text { Flag name }\end{array}$ & $\begin{array}{l}\text { Exchange File } \\
\text { Parameter Name }\end{array}$ & $\begin{array}{l}\text { Exchange File } \\
\text { Flag Name }\end{array}$ & Units \\
\hline station & & STANBR & & \\
\hline day & & DATE & & \\
\hline month & & DATE & & \\
\hline year & & DATE & & \\
\hline latitude & & LATITUDE & & decimal degrees \\
\hline $\begin{array}{l}\text { longitude } \\
\text { cruiseno }\end{array}$ & & LONGITUDE & & decimal degrees \\
\hline depth & & & & meters \\
\hline temperature & & CTDTMP & & ${ }^{\circ} \mathrm{C}$ \\
\hline salinity & sf & SALNTY & SALNTY_FLAG_W & \\
\hline pressure & & CTDPRS & & decibars \\
\hline alk & alkf & ALKALI & ALKALI_FLAG_W & micromole $\mathrm{kg}^{-1}$ \\
\hline
\end{tabular}

For a complete list of parameters for the CARINA data base, see Key et al. (2009). Note the different names for the parameters in the Exchange files (the individual cruise files) and the merged data product.

\section{Introduction}

CARINA is a database of carbon and carbon relevant data from hydrographic cruises in the Arctic, Atlantic and Southern Oceans. The project was formed as an essentially informal, unfunded project in Kiel, Germany, in 1999, with the main goal to create a database of carbon relevant variables in the ocean to be used for accurate assessments of oceanic carbon inventories and uptake rates. Not only the collection of data, but also the quality control of the data has been a main focus of the project, with both primary and secondary quality control (QC) of the data having been performed. The CARINA database consists of essentially two parts:

The first part are the individual cruise files where all the measured data, and their quality flags, are stored. These files are in WHP (WOCE Hydrographic Program) exchange format where the first lines consist of the condensed metadata. There are essentially no calculated neither interpolated values in the individual cruise files, with the exceptions of pressure calculated from depth and some bottle salinities that were taken from ctdsal. No adjustments have been applied to any of these values, with the exception that all $\mathrm{pH}$ measurements were converted to the seawater $\mathrm{pH}$ scale at $25^{\circ} \mathrm{C}$.

The second part of CARINA are three merged quality controlled and adjusted data files; one each for the Atlantic Ocean, Arctic Mediterranean Seas and Southern Ocean regions. These files contain all the CARINA data and include: 1) interpolated values for nutrients, oxygen and salinity if those data are missing and if interpolation could be made according to criteria described in Key et al. (2009) (this special issue); calculated carbon parameters (e.g. if total dissolved inorganic carbon $\left(\mathrm{TCO}_{2}\right)$ and Total Alkalinity $\left(A_{T}\right)$ were measured, $\mathrm{pH}$ can be calculated). Calculated and interpolated values have the quality flag " 0 ". All the values in the merged data file have been adjusted according to the values in Table 1 and described in Sect. 5. In many cases there are more reported parameters in the individual cruise files that has been included in the secondary QC, such as ${ }^{14} \mathrm{C},{ }^{13} \mathrm{C}$ and $\mathrm{SF}_{6}$.

This report describes the consistency analysis of alkalinity measurements of the Atlantic Ocean part of the CARINA database (CARINA-ATL). A more comprehensive description of the complete CARINA data base can be found in Key et al. (2009) (this special issue), for an overview of the North Atlantic CARINA data, see Tanhua et al. (2009a) (this special issue). Alkalinity reports for other areas included in CARINA can be found in the following reports: Artic Ocean by Jutterström et al. (2009), Nordic Seas by Olsen et al. (2009), Atlantic Sector of Southern Ocean by Hoppema et al. (2009), Indian Sector of Southern Ocean by Lo Monaco et al. (2009) and Pacific Sector of Southern Ocean by Sabine et al. (2009).

The Total Alkalinity in sea water is defined as "...the number of moles of hydrogen ion equivalent to the excess of proton acceptors (bases formed from weak acids with a dissociation constant $K \leq 10^{-4.5}$, at $25^{\circ} \mathrm{C}$ and zero ionic strength) over proton donors (acids with $K>10^{-4.5}$ ) in one kilogram of sample." (Dickson, 1981). $A_{T}$ is one of the four basic related parameters of the carbon dioxide " $\mathrm{CO}_{2}$ " system in seawater, with the others being total dissolved inorganic carbon $\left(C_{T}\right)$, the fugacity of dissolved $\mathrm{CO}_{2}\left(f \mathrm{CO}_{2}\right)$, and $\mathrm{pH}$. If at least two of these are known, then the remaining parameters can be calculated and the entire $\mathrm{CO}_{2}$ system determined using thermodynamic constants for a given temperature, salinity and pressure.

High quality seawater carbon data are critical for detecting small changes in the $\mathrm{CO}_{2}$ system. Both $A_{T}$ and $C_{T}$ are used in a number of methods for calculating the anthropogenic $\mathrm{CO}_{2}$ signal, most specifically those that employ back-calculation techniques. $A_{T}$ is a key in both determining changes in $C_{T}$ produced by $\mathrm{CaCO}_{3}$ dissolution (Feely et al., 2002) and establishing concentrations of $C_{T}$ in surface waters at equilibrium with the atmosphere, whether at historical, present, or future $\mathrm{CO}_{2}$ levels Furthermore, many measurements of the $\mathrm{CO}_{2}$ system in seawater have been performed using the 


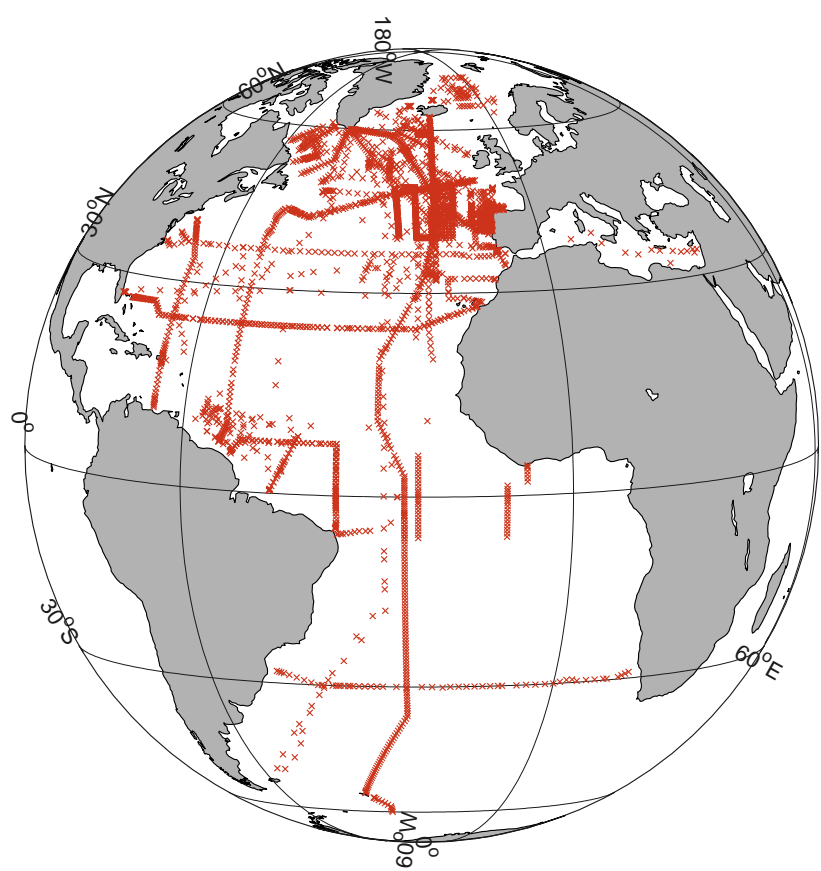

Figure 1. Map of stations with alkalinity data in the CARINA-ATL dataset.

$A_{T}-\mathrm{pH}$ pair for determining $\mathrm{C}_{T}$. For these reasons, this is a key parameter for the CARINA objectives.

\section{Data}

Alkalinity data included in the CARINA-ATL dataset originates from a multitude of international research groups using a number of different analysis methods. Whilst most of the $A_{T}$ data was determined using closed cell potentiometric titrations (Dickson et al., 2007), many measurements were also made by potentiometric titration at end-point in open cell (Mintrop et al., 2000).

The CARINA-ATL dataset has a total of 52043 alkalinity samples, coming from 4080 stations and 63 cruises. Of these, 46961 samples came from measurements, and were flagged with a "2". The remaining 5082 samples came from carbon calculations with the final adjusted data, and so were flagged with a "0". Figure 1 shows the location of the stations with alkalinity data in CARINA-ATL

For consistency with historical data, a further 12 WOCE/GLODAP reference cruises were included, giving a total of 75 cruises and 65531 samples. Primary quality control - consisting of outlier and scatter identification - led to 2 cruises and 5738 samples being discarded. For the crossover analyses, only data deeper than $1500 \mathrm{~m}$ were used, leading to a number of cruises being omitted from the analyses. In total, 12828 CARINA-ATL samples and 2878 WOCE/GLODAP samples are compared here.
Of the 53 cruises included in the crossover analysis, alkalinity data from 31 had been generated using certified reference materials (CRMs) to test or calibrate the titration system. The remaining 22 did not use CRM at all, instead using an alternative solution for standardization (Dickson et al., 2007). The most typical reported analytical error was around $1 \%, \sim 2.5 \mu \mathrm{mol} \mathrm{kg}^{-1}$. However, similar crossover exercises (Key et al., 2004; Sabine et al., 2005; Wanninkhof et al., 2003) performed on older data estimated an overall accuracy of $\pm 5 \mu \mathrm{mol} \mathrm{kg}^{-1}$.

The overall objective of this work was to assess the quality of the Atlantic CARINA alkalinity data in order to generate a mutually consistent database, by checking for apparent offsets for each cruise considering all the information reported by different sources (Tanhua et al., 2009b) For $A_{T}$, the minimum adjustment to be applied to the final dataset following the identification of an additive offset was established as $\pm 6 \mu \mathrm{mol} \mathrm{kg}^{-1}$, as was the case for the previous crossover comparison study for the North Atlantic (Wanninkhof et al., 2003).

\section{Methods}

The methods and techniques applied here are described in detail in Tanhua et al. (2009b) . In summary, the procedure essentially entails the comparison of data from separate cruises whose tracks cross or at least come close to each other, so-called crossover analyses. Before that comparison, a primary quality control (1st QC) consisting on outlier and scatter identification has been performed (Key et al., 2009). Only data that were flagged "good" during this primary QC procedure were considered in this process. With the application of various software packages (Tanhua et al., 2009b) generating statistical and objective information about the offsets between pairs of cruises, as well as the graphics needed to visually verify the computer generated offsets. For each crossover analysis, $A_{T}$ data from samples deeper than $1500 \mathrm{~m}$ were compared on sigma-4 density surfaces generating an offset and a standard deviation of this difference, as well as totaling the number of contributing stations and samples. For alkalinity, additive offsets (and adjustments) were determined.

Slightly different procedures have been performed in the Nordic Seas (Olsen, 2009) due to the lower variability in deep waters in that area.

In this work, the semi-automated crossover procedure was run for all possible pairs of Atlantic cruises. Next, the crossover results were then visually inspected in order to ensure quality and to check the analysis had run correctly. Only "good" quality crossovers were selected, and those results were used for subsequent cruise adjustment calculations. Good crossovers had enough sample data to yield a reasonably uniform additive offset over the entire zone of analysis, leading to parallel cruise profiles. Standard deviations for 


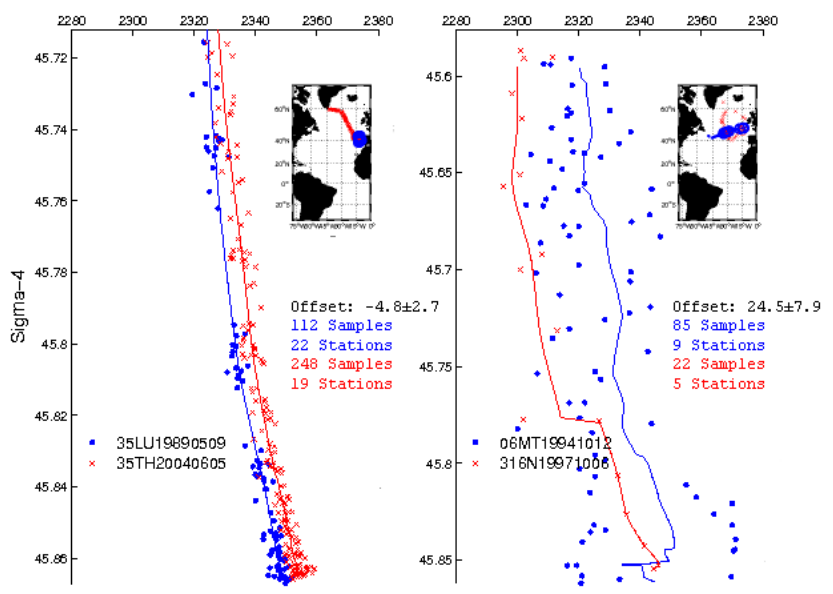

Figure 2. Crossover between the cruises 35LU19890509 and 35TH20040605 (a) and the cruises 06MT19941012 and 316N19971006 (b).

individual cruise data and difference profiles were also used to provide more information on crossover quality.

In Fig. 2, two examples of $A_{T}$ crossovers are shown; the contrast between a good crossover (on the left) and a bad one (on the right) can be easily appreciated, as well as the lack of data and dispersion. The quality of the offset is assessed when the standard deviation of the offset is compared $( \pm 2.7$ versus $\pm 7.9 \mu \mathrm{mol} \mathrm{kg}^{-1}$ ).

After this first iteration, automated procedures described by Tanhua et al. (2009b) weighted the crossover quality by statistical parameters for later adjustment calculations for all cruises. This process was applied for all available cruise crossovers in the Atlantic. In total, 337 individual crossovers were obtained for $A_{T}$.

The final offsets and statistics were used as the input for an inverse least squares procedure (Tanhua et al., 2009b). Inversion results generated a set of suggested corrections for all cruises included in the analysis that minimized the differences. Figure 3 shows the offsets for all $A_{T}$ crossovers in the Atlantic region before (pink dots), and after (blue dots) the adjustments were applied to each cruise. The convergence to values inside the bounds can be easily appreciated for values after inversions. The standard error for the original crossovers is $10.5 \mu \mathrm{mol} \mathrm{kg}^{-1}$ whereas the standard error for the adjusted ones is $4.7 \mu \mathrm{mol} \mathrm{kg}-1$.

In order to ensure the highest quality results from the inversion and to help get a more accurate and consistent solution to the system, a small subset of cruises were a priori defined as "core". These were chosen according to their geographical extent (i.e. covering a large distance) and expected high data quality (i.e. WOCE/CLIVAR quality), and were agreed upon by the CARINA Atlantic group. Offsets identified towards "core" cruises received a higher weighting in the inversion minimization process (Tanhua et al., 2009b). Once the full result of $A_{T}$ offsets for each cruise had been

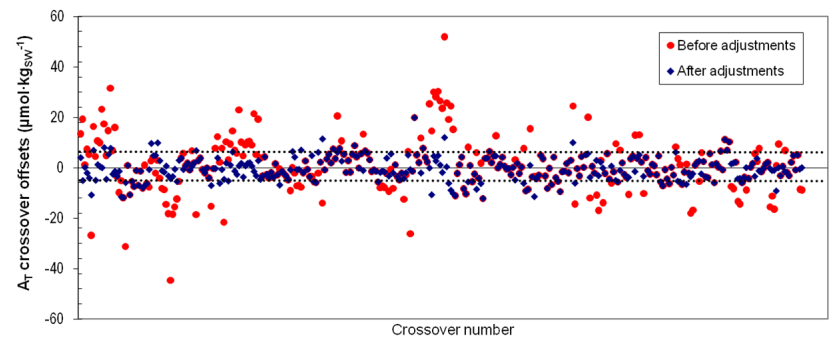

Figure 3. Crossover alkalinity offsets obtained with original database and after adjustments were applied.

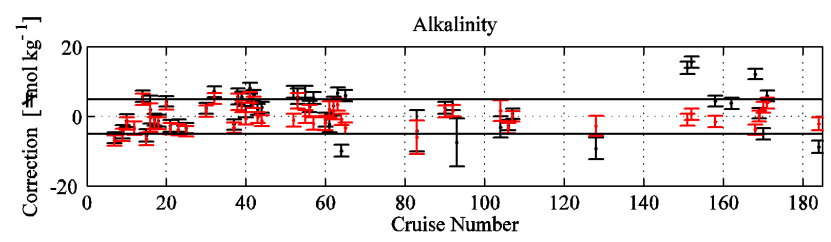

Figure 4. Mean and standard deviation of the offset for each cruise before (black) and after (red) the adjustments were applied.

generated, only the suggested corrections that exceeded a predefined limit of $\pm 6 \mu \mathrm{mol} \mathrm{kg}{ }^{-1}$ were applied. These subsets of high values were used as starting point to establish the final adjustment values to be proposed. The decision on final values was made manually and by consensus among the CARINA collaborators. For this decision, subjective factors such as the location, use of CRMs, technique, date, quantity and quality of crossovers, or some particularly relevant crossovers were used. Only those offsets that were strongly supported by the analysis were finally adopted and subsequently applied to the measured results. The corrections that were actually applied to the data product are, in following, referred to as an adjustment.

After the need for an adjustment and its magnitude were established for each cruise, the values were applied to the original database, and the full process of crossovers and inversions repeated. The result of this second iteration was a very useful way of validating the proposed offsets. Figure 4 shows the corrections values for each cruise obtained after the first inversion procedures (values in black), and the corrections obtained after the second iteration (values in red). The results from the second inversion clearly show that the remaining offsets are lower, and most of them fit within the chosen minimum error boundary

\subsection{Overall accuracy}

The offsets for the crossovers applied to the data product were used to estimate the overall accuracy of the alkalinity data (Fig. 5). The weighted mean (WM) was calculated for alkalinity by using the absolute value of the offset $(D)$ of the 


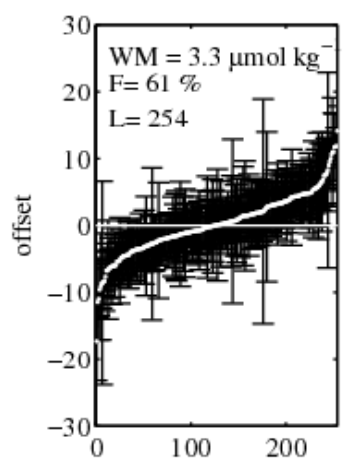

Figure 5. Sorted offsets calculated for the crossovers in the CARINA-ATL data after adjustments have been applied. WM: the weighted mean of the offsets (see text); $F$ : the percentage of offsets indistinguishable from 1 within their uncertainty; $L$ : the number of crossovers.

$L$ crossovers with the uncertainty $(\sigma)$ :

$W M=\frac{\sum_{i=1}^{L} D(i) /\left(\sigma(i)^{2}\right.}{\sum_{i=1}^{L} 1 /\left(\sigma(i)^{2}\right.}$

Based on this analysis we have estimated the accuracy of the CARINA-ATL alkalinity data to $3.3 \mu \mathrm{mol} \mathrm{kg}{ }^{-1}$.

\section{Results}

Results are summarized in Table 1. This table shows the cruises in the CARINA-ATL dataset with $A_{T}$ data, and the summary of adjustments applieds. The following data is presented:

- Cruise ID: CARINA assigned identification number for the cruise.

- Cruise Expocode: String identifying the cruise. This is composed by a country code (two numbers), vessel code (two characters or numbers) and the departure date in year, month, day format (YYYYMMDD).

- Region: Location of the cruise. All cruises belong to Atlantic Ocean (NA), but some overlap with the Arctic Mediterranean Seas (AMS) or Southern Ocean (SO) areas.

- Core: Indicates whether or not the cruise is a core cruise for the crossover analysis.

- CRM: Indicates whether or not CRMs were used during instrumental analysis.

- WLSQ adj: Result of the inversion process through the Weighted Least Squares method (Tanhua et al., 2009b).

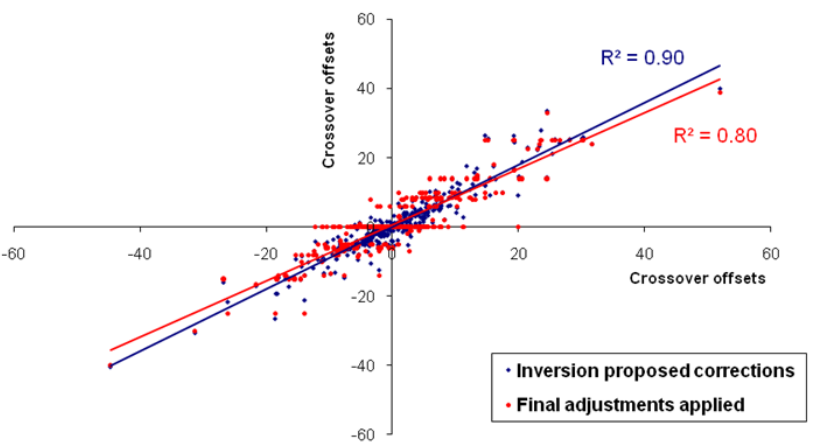

Figure 6. Original (x-axis) versus post-adjust (y-axis) offsets for the all crossover in the Atlantic Ocean after applying the full solution (blue) or the final applied solution given in the last column of Table 1 (pink).

- WDLSQ adj: Result of the inversion process through the Weighted Damped Least Squares method (Tanhua et al., 2009b).

- Adjustment: Adjustments applied for the cruises in the merged data product. All adjustments are fully supported by the CARINA group and no adjustments smaller than $\pm 6 \mu \mathrm{mol} \mathrm{kg}^{-1}$ are applied.

Figure 6 is a comparison between the original corrections and the final adjustments applied. Blue dots represent offsets obtained by applying full solution (all corrections); pink dots represent offsets obtained with the final adjustments applied to the data product (Table 1). The relation for the applied adjustments (pink dots) has only a slightly lower correlation coefficient than for the full solution.

In the following paragraph a set of figures and comments are presented for each cruise summarizing all crossover offsets with their standard deviation. Each figure shows the following information:

- Green dots: "Offsets". These values are the offsets taken directly from each crossover. The standard deviation is shown as error bars on these dots.

- Yellow line indicates the additive correction calculated by inversions for the cruise. Note that the correction and offsets are of opposite sign.

- Black stars indicate the correction calculated by inversions for the other cruises that intersect this cruise.

- Blue squares: "Predicted offset" shows the calculated offset that would be obtained by applying all inversion corrections to the cruises.

- Red dots: These are the residuals between the "Offsets" (Green dots) and "Predicted Offsets" (Blue squares)

- c suffix in the upper X-axis labels stands for Core Cruises. 
Table 1. CARINA-ATL dataset with alkalinity data and adjustments applied.

\begin{tabular}{|c|c|c|c|c|c|c|c|}
\hline Cruise ID & Expocode & Region & Core & CRM & WLSQ adj \pm STD & WDLSQ adj $\pm 95 \% \mathrm{CI}$ & Adjustment $\mu \mathrm{mol} \mathrm{kg}^{-1}$ \\
\hline 7 & 06BE20001128 & NA & & & & & \\
\hline 8 & 06GA19960613 & NA & & & & & \\
\hline 9 & 06GA20000506 & NA & & & & & \\
\hline 10 & 06MT19920316 & NA & & & & & \\
\hline 12 & 06МT19920509 & NA & & $\mathrm{x}$ & $-27.9 \pm 1.3$ & $-25.1 \pm 1.6$ & -25 \\
\hline 14 & 06МT19920701 & $\mathrm{NA}+\mathrm{AMS}$ & & & & & \\
\hline 15 & 06МТ19940219 & NA & & & & & \\
\hline 16 & 06MT19941012 & NA & & & & & \\
\hline 17 & 06MT19941115 & NA & & & & & \\
\hline 18 & 06МТ19960613 & NA & & & & & \\
\hline 20 & 06МT19960910 & NA & & & & & \\
\hline 21 & 06МТ19970107 & NA & & & & & \\
\hline 23 & 06MT19970515 & NA & & & & & \\
\hline 25 & 06MT19970707 & NA & & & & & \\
\hline 26 & 06МТ19970815 & NA & & & & & \\
\hline 28 & 06MT19990610 & NA & & & & & \\
\hline 30 & 06MT19990711 & NA & & & & & \\
\hline 32 & 06МТ19990813 & NA & & & & & \\
\hline 44 & 06MT20010507 & NA & $\mathrm{x}$ & $\mathrm{x}$ & $7.4 \pm 0.8$ & $6.2 \pm 1.2$ & 6 \\
\hline 51 & 06MT20010620 & NA & & & & & \\
\hline 52 & 06MT20010717 & NA & & & $6.7 \pm 1.0$ & $7.1 \pm 1.0$ & 7 \\
\hline 53 & 06MT20011018 & NA & & & & & \\
\hline 54 & 06МT20020607 & NA & & & & & \\
\hline 55 & 06MT20021013 & NA & & & $6.7 \pm 0.9$ & $6.5 \pm 1.3$ & 6 \\
\hline 56 & 06MT20030626 & NA & & & & & \\
\hline 57 & 06MT20030723 & NA & & & $4.8 \pm 0.9$ & $4.3 \pm 1.7$ & 6 \\
\hline 60 & 06МT20030831 & NA & & & & & \\
\hline 61 & 06MT20040311 & NA & & $\mathrm{x}$ & $-3.9 \pm 1.8$ & $-5.1 \pm 0.8$ & -6 \\
\hline 62 & 18HU19920527 & NA & & & & & \\
\hline 63 & 18HU19930405 & NA & & & & & \\
\hline 64 & 18HU19930617 & NA & & & $-10.2 \pm 0.9$ & $-9.6 \pm 1.1$ & -10 \\
\hline 65 & 18HU19931105 & NA & & & $5.5 \pm 0.8$ & $8.1 \pm 0.9$ & 8 \\
\hline 66 & 18HU19940524 & NA & & & & & \\
\hline 68 & 18HU19941012 & NA & & & & & \\
\hline 69 & 18HU19950419 & NA & & & & & \\
\hline 84 & 18HU19970509 & NA & & & & & \\
\hline 85 & 29CS19771007 & NA & & & & & \\
\hline 86 & 29CS19930510 & NA & & & & & \\
\hline 87 & 29GD19821110 & NA & & & & & \\
\hline 89 & 29GD19831201 & NA & & & & & \\
\hline 90 & 29GD19840218 & NA & & & & & \\
\hline 92 & 29GD19840711 & NA & & & & & \\
\hline 93 & 29GD19860904 & NA & & & & & \\
\hline 94 & 29HE19980730 & NA & & & & & \\
\hline 95 & 29HE20010305 & $\mathrm{NA}+\mathrm{SO}$ & & & & & \\
\hline 106 & 29HE20020304 & $\mathrm{NA}+\mathrm{SO}$ & & $\mathrm{x}$ & $-4.6 \pm 2.6$ & $-6.8 \pm 1.6$ & -6 \\
\hline 107 & 29HE20030408 & NA & & & & & \\
\hline 108 & 31AN19890420 & NA & & & & & \\
\hline 109 & $316 N 19971005$ & NA & & & & & \\
\hline 113 & 316 N20010627 & NA & & & & & \\
\hline 125 & 316 N20030922 & NA & & & & & \\
\hline 153 & 316 N20031023 & NA & & & $13.7 \pm 0.9$ & $13.8 \pm 0.7$ & 14 \\
\hline 154 & 32EV19910328 & NA & & & $15.2 \pm 0.7$ & $14.4 \pm 1.4$ & 14 \\
\hline 158 & $32 \mathrm{OC} 19950529$ & NA & & & & & \\
\hline 160 & 33LK19960415 & NA & & & $4.1 \pm 0.7$ & $5.2 \pm 0.7$ & 5 \\
\hline 164 & 33RO19980123 & NA & & & & & \\
\hline 165 & 33RO20030604 & NA & & & & & \\
\hline 168 & 33RO20050111 & $\mathrm{NA}+\mathrm{SO}$ & & & & & \\
\hline 170 & 33SW20010102 & NA & & & $11.9 \pm 0.4$ & $14.9 \pm 1.6$ & 15 \\
\hline 171 & 33SW20030418 & NA & & & & & \\
\hline 172 & 34AR19970805 & $\mathrm{NA}+\mathrm{AMS}$ & $\mathrm{x}$ & $\mathrm{x}$ & $-5.3 \pm 0.6$ & $-8.5 \pm 0.6$ & -9 \\
\hline 173 & $35 \mathrm{~A} 320010203$ & NA & & & & & \\
\hline \multirow[t]{2}{*}{188} & $35 \mathrm{~A} 320010322$ & NA & & & $-9.3 \pm 1.0$ & $-8.1 \pm 2.0$ & -8 \\
\hline & 323019940104 & $\mathrm{NA}+\mathrm{SO}$ & $\mathrm{x}$ & $\mathrm{x}$ & $-10.9 \pm 2.8$ & $-8.9 \pm 0.8$ & -8 \\
\hline
\end{tabular}




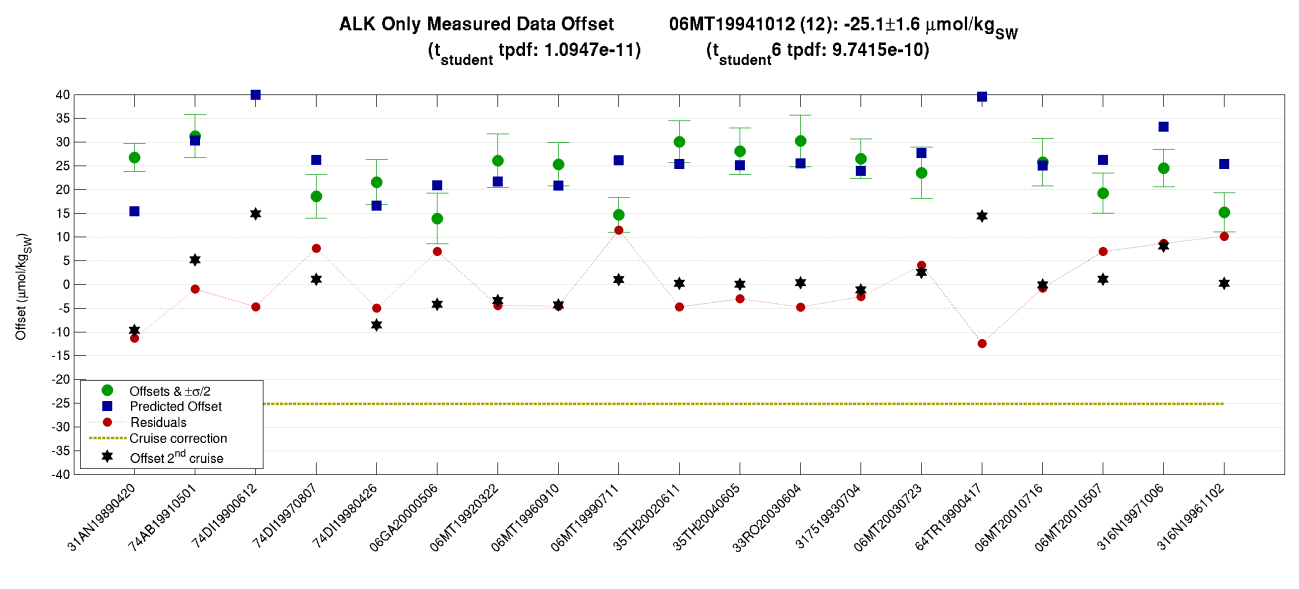

Figure 7. Cruise crossover information plot for 06MT19941012.

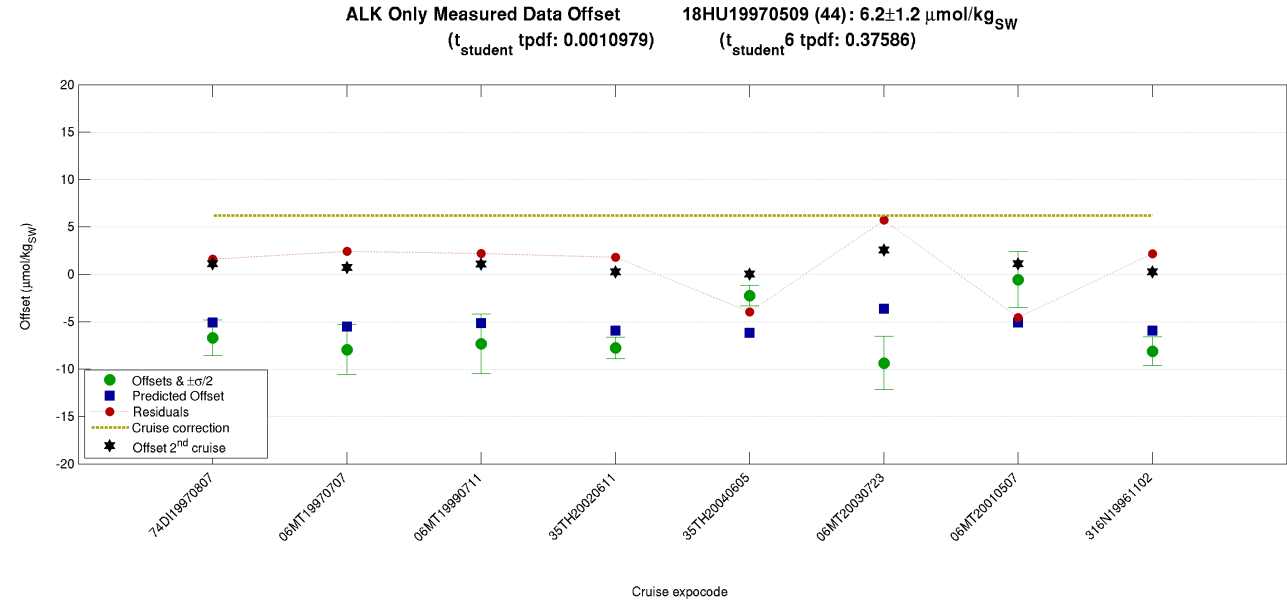

Figure 8. Cruise crossover information plot for 18HU19970509.

\section{Cruises}

In this section, an assessment and description of the adjustments applied to cruises for CARINA-ATL database is made. CARINA identifiers for the cruises are the numbers indicated between the parentheses. Exact data locations can be found at the CARINA website: http://cdiac.ornl.gov/oceans/ CARINA/Carina_inv.html.

\subsection{Cruise 06MT19941012 (12) (Fig. 7)}

This is the so called MT30/2 cruise, on board Meteor and along WOCE leg A02 section, in the North Atlantic. It has 53 stations taken with a 24 place rosette system. A closed cell potentiometric titration method was used on measurements, and CRM Batch \#22 was used as reference. The report indicates an estimated precision of $\pm 3 \mu \mathrm{mol} \mathrm{kg}^{-1}$ and an accuracy $\pm 6 \mu \mathrm{mol} \mathrm{kg}^{-1}$. This cruise has 19 crossovers. The inversions suggest a correction of $-25.1 \mu \mathrm{mol} \mathrm{kg}{ }^{-1}$. Most of the residuals fit within $\pm 10 \mu \mathrm{mol} \mathrm{kg}{ }^{-1}$, with half part of them inside $\pm 5 \mu \mathrm{mol} \mathrm{kg}{ }^{-1}$ after corrections applied. No good fit exists with the core-cruises however. The crossovers with 74DI19970807 and 06GA20000506 suggest a minor offset, but the other four core cruises (two of them GLODAP), suggest a correction of around $-28 \mu \mathrm{mol} \mathrm{kg}^{-1}$. Based on this evidence, an adjustment of $-25 \mu \mathrm{mol} \mathrm{kg}^{-1}$ was applied to the alkalinity data.

\subsection{Cruise 18HU19970509 (44) (Fig. 8)}

This is the AR07Wh, a CCHDO cruise on board R/V Hudson, in the Labrador Sea. It has 13 stations taken with a 24 place Rosette system with ten-liter bottles. CRM analyses were used for standardization and precision was $2.7 \mu \mathrm{mol} \mathrm{kg}^{-1}$. There are eight crossovers giving a fitted correction of $6.2 \mu \mathrm{mol} \mathrm{kg}^{-1}$. The suggested adjustment for this cruise is therefore $6 \mu \mathrm{mol} \mathrm{kg}{ }^{-1}$. Most of the residuals fit very close to 0 and keep inside $\pm 5 \mu \mathrm{mol} \mathrm{kg}^{-1}$ after offsets applied. 


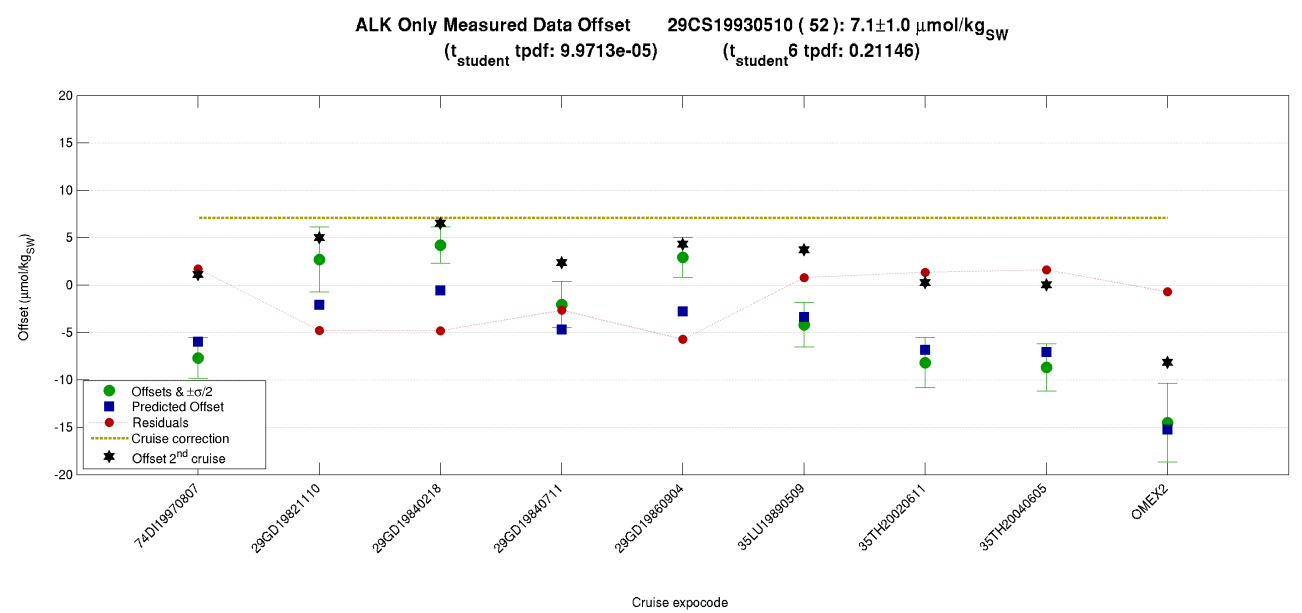

Figure 9. Cruise crossover information plot for 29CS19930510.

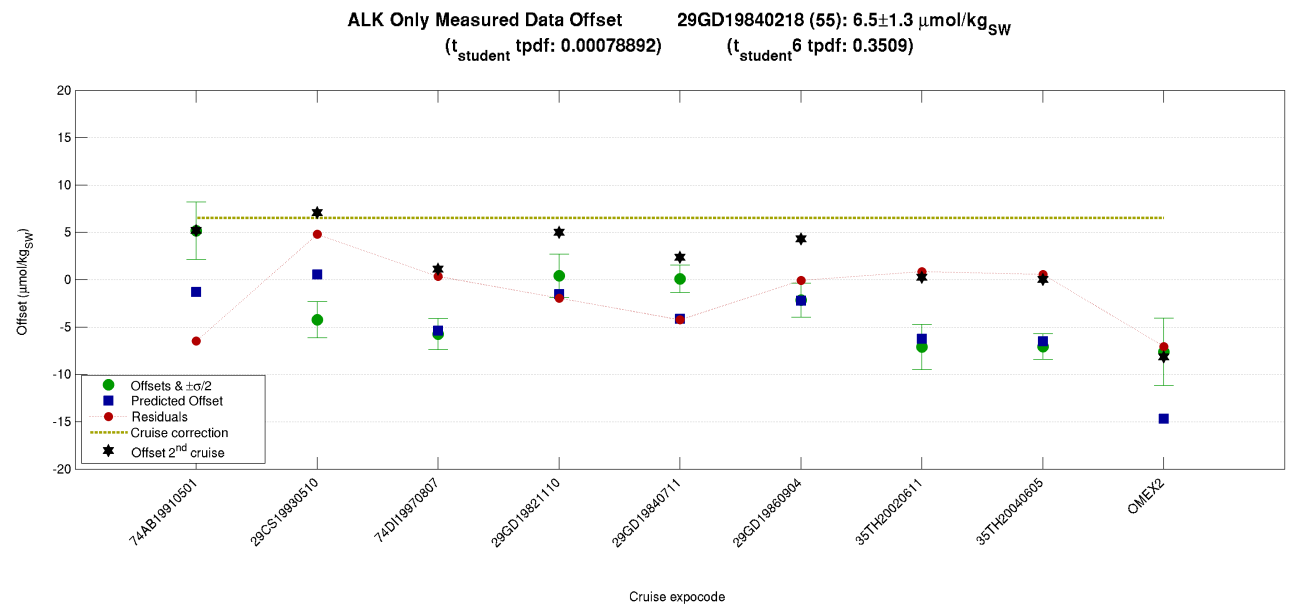

Figure 10. Cruise crossover information plot for 29GD19840218.

There are very good fits with four core cruises. Based on this evidence, an adjustment of $6 \mu \mathrm{mol} \mathrm{kg}^{-1}$ was applied to the alkalinity data.

\subsection{Cruise 29CS19930510 (52) (Fig. 9)}

This is the so called MORENA-I cruise conducted on board $\mathrm{R} / \mathrm{V}$ Cornide de Saavedra, along WOCE line AR16e in the Atlantic area, close to NW Spain. It has 92 stations and 24 sampling levels using a rosette system. CRMs were not used for these measurements. There are nine crossovers. The fitted correction of inversions is $7.1 \mu \mathrm{mol} \mathrm{kg}^{-1}$. The suggested adjustment is therefore $7 \mu \mathrm{mol} \mathrm{kg}^{-1}$. Crossovers with three core cruises show very low residuals after offset applied. Based on this evidence, an adjustment of $7 \mu \mathrm{mol} \mathrm{kg}{ }^{-1}$ was applied to the alkalinity data.

\subsection{Cruise 29GD19840218 (55) (Fig. 10)}

This is the so called GALICIA-VII cruise, on board R/V Garcia del Cid in the Atlantic area close to NW Spain. It has 33 stations taken on a hydrocast with 1.71 Niskin bottles.. A precision of $0.1 \%$ and accuracy of $1.4 \mu \mathrm{mol} \mathrm{kg}{ }^{-1}$ has been reported. No CRMs were used during the analysis. There are nine crossovers giving a fitted correction of $6.5 \mu \mathrm{mol} \mathrm{kg}{ }^{-1}$. The suggested adjustment is $+6 \mu \mathrm{mol} \mathrm{kg}{ }^{-1}$. Almost all residuals fit very close to 0 and stay within $\pm 5 \mu \mathrm{mol} \mathrm{kg}^{-1}$ after offsets applied. There are very good fits with three core cruises. Based on this evidence, an adjustment of $6 \mu \mathrm{mol} \mathrm{kg}^{-1}$ was applied to the alkalinity data. 


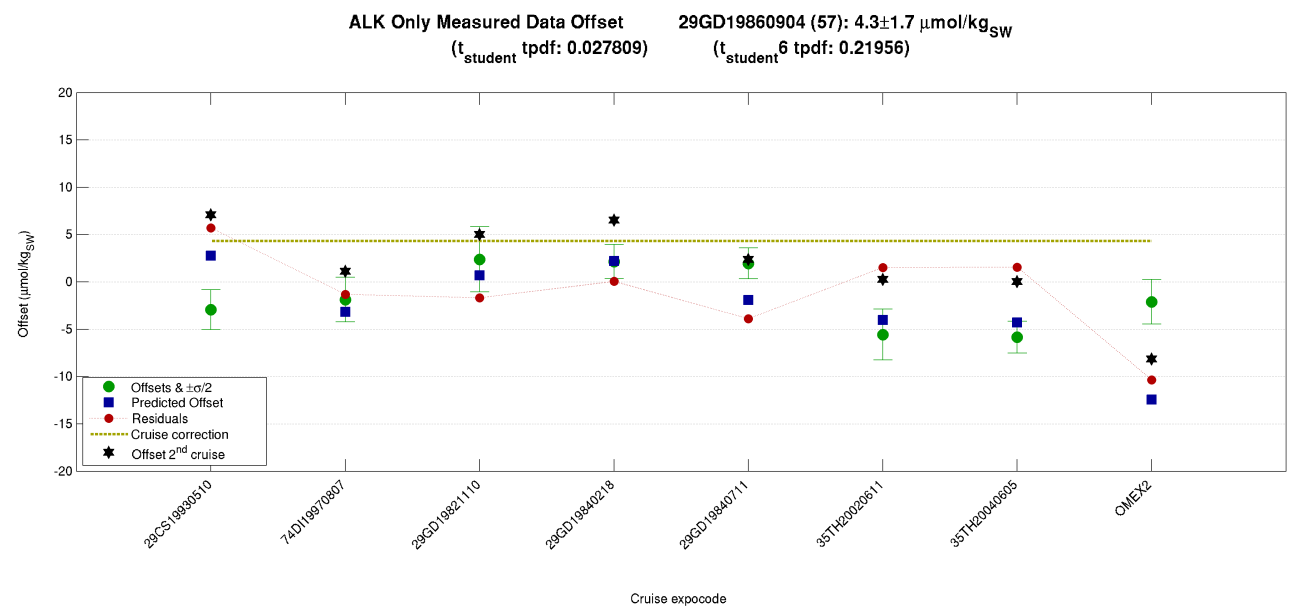

Figure 11. Cruise crossover information plot for 29GD19860904.

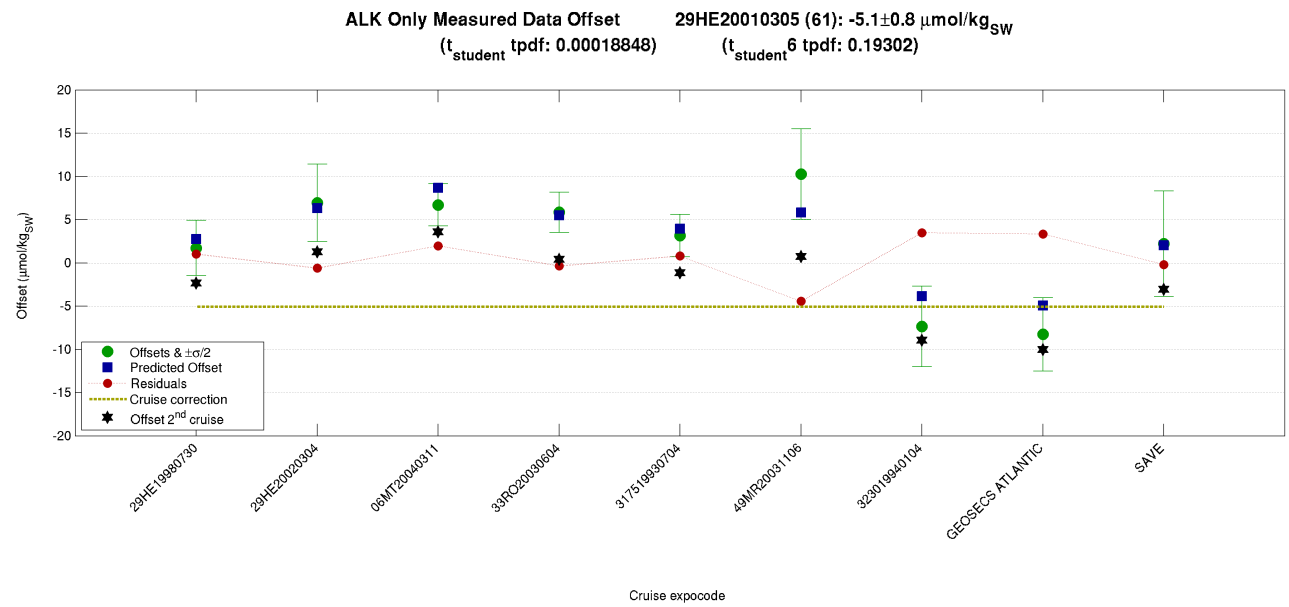

Figure 12. Cruise crossover information plot for 29HE20010305.

\subsection{Cruise 29GD19860904 (57) (Fig. 11)}

This is the so called GALICIA-IX cruise, on board R/V Garcia del Cid in the Atlantic area close to NW Spain. It has 50 stations taken on hydrocasts with $1.7 \mathrm{~L}$ Niskin bottles. A precision of $0.1 \%$ and accuracy of $1.4 \mu \mathrm{mol} \mathrm{kg}^{-1}$ has been reported. No CRMs were used.

There are nine crossovers giving a fitted correction of $+4.3 \mu \mathrm{mol} \mathrm{kg}{ }^{-1}$. The suggested adjustment is $+6 \mu \mathrm{mol} \mathrm{kg}{ }^{-1}$ as t-student statistical checks show that the proposed offset is indistinguishable from $6 \mu \mathrm{mol} \mathrm{kg}^{-1}$. Almost all residuals fit very close to zero and keep inside $\pm 5 \mu \mathrm{mol} \mathrm{kg}^{-1}$ after offsets applied. There are very good fits with three core cruises. Based on this evidence, an adjustment of $6 \mu \mathrm{mol} \mathrm{kg}^{-1}$ was applied to the alkalinity data.

\subsection{Cruise 29HE20010305 (61) (Fig. 12)}

This is the so called FICARAM II cruise, conducted on $\mathrm{R} / \mathrm{V}$ Hesperides along WOCE section A17 in the Western South Atlantic area. It has 29 full depth stations taken with a 24 place rosette system. CRM batches 41 and 51 were used. Uncertainty is $1.4 \mu \mathrm{mol} \mathrm{kg}{ }^{-1}$ according to cruise report. There are 9 crossovers, two of them in the Southern Ocean giving a fitted correction of $-5.1 \mu \mathrm{mol} \mathrm{kg}^{-1}$. Analysis of cruise documentation seems to suggest a correction of $-5 \mu \mathrm{mol} \mathrm{kg}{ }^{-1}$. The proposed adjustment is $-6 \mu \mathrm{mol} \mathrm{kg}{ }^{-1}$, as it is within the offset error and is better supported than no adjustment. All residuals are very close to 0 and fit inside $\pm 5 \mu \mathrm{mol} \mathrm{kg}{ }^{-1}$. There are very good fits with five core cruises. Based on this evidence, an adjustment of $-6 \mu \mathrm{mol} \mathrm{kg}^{-1}$ was applied to the alkalinity data. 


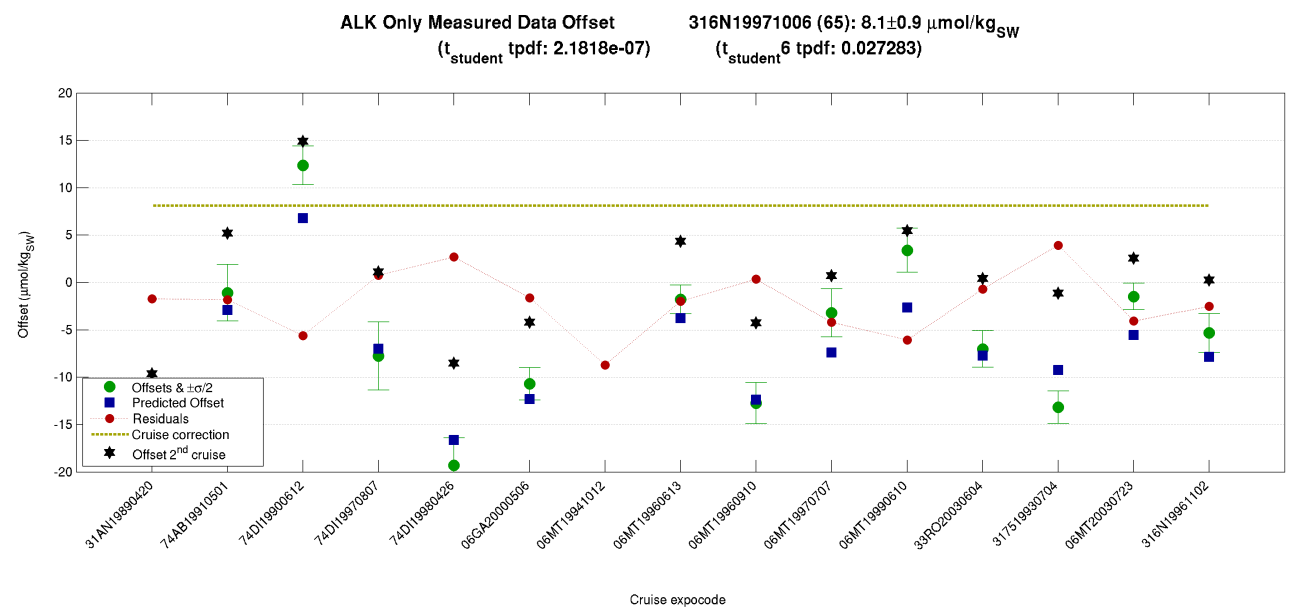

Figure 13. Cruise crossover information plot for 316N19971005.

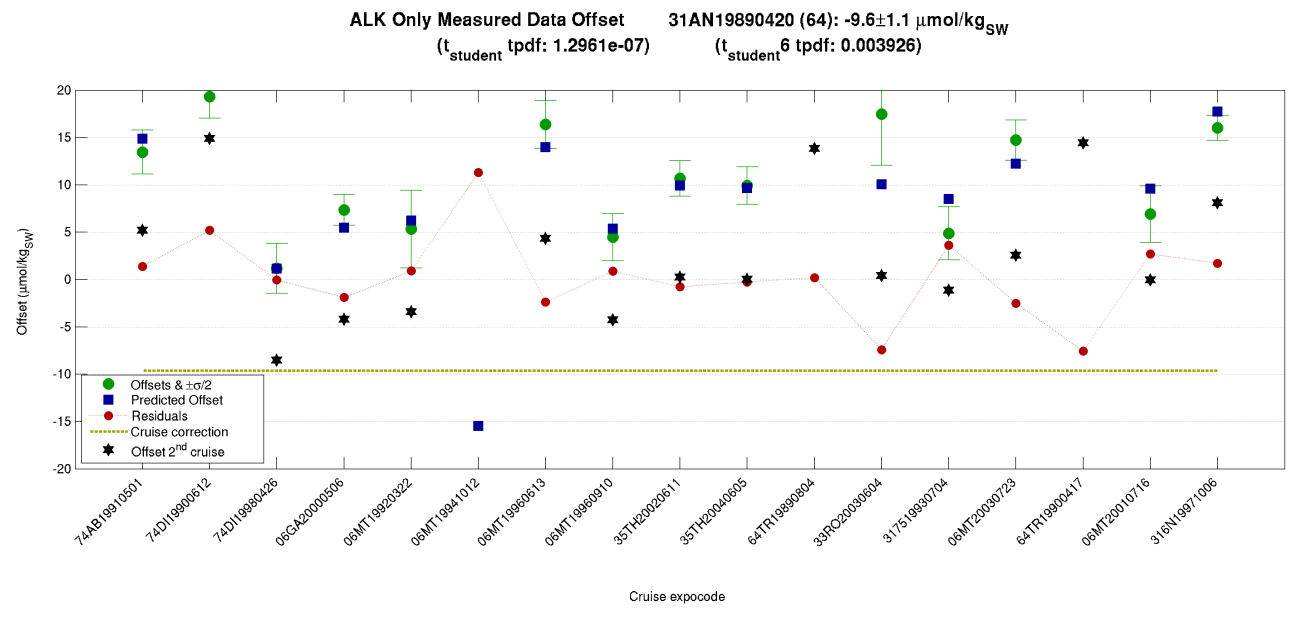

Figure 14. Cruise crossover information plot for 31AN19890420.

\subsection{Cruise 316N19971005 (65) (Fig. 13)}

This is the so called KN154/2 cruise, on board R/V Knorr along the WOCEAR24b section in the NW Atlantic area. It has 162 stations and 24 sampling levels using a rosette system. No reference to the use of CRM was reported. There are 15 crossovers giving a fitted correction of $+8.1 \mu \mathrm{mol} \mathrm{kg}{ }^{-1}$. The suggested adjustment is $+8 \mu \mathrm{mol} \mathrm{kg}^{-1}$. Excepting one, all inversion residuals fit inside $\pm 6 \mu \mathrm{mol} \mathrm{kg}^{-1}$. The cruise has a good fit with three core-cruises. Based on this evidence, an adjustment of $8 \mu \mathrm{mol} \mathrm{kg}^{-1}$ was applied to the alkalinity data.

\subsection{Cruise 31AN19890420 (64) (Fig. 14)}

This is the so called 31A119 cruise, on board R/V Atlantis II and conducted along a section at about $20^{\circ} \mathrm{W}$ from $47^{\circ} \mathrm{N}$ to $60^{\circ} \mathrm{N}$. This cruise has 51 stations taken with a rosette system. According the cruise report, the values seem to be about 5 to $10 \mu \mathrm{mol} \mathrm{kg}^{-1}$ too high in relation to OACES93 and A16N2003. CRMs were not used. The fitted correction is $-9.6 \mu \mathrm{mol} \mathrm{kg}^{-1}$. The inversions suggest an adjustment of $-10 \mu \mathrm{mol} \mathrm{kg}^{-1}$. Crossovers with core cruises support the proposed offset very well. In addition, GLODAP 317519930704 supports this adjustment. Based on this evidence, an adjustment of $-10 \mu \mathrm{mol} \mathrm{kg}^{-1}$ was applied to the alkalinity data. 


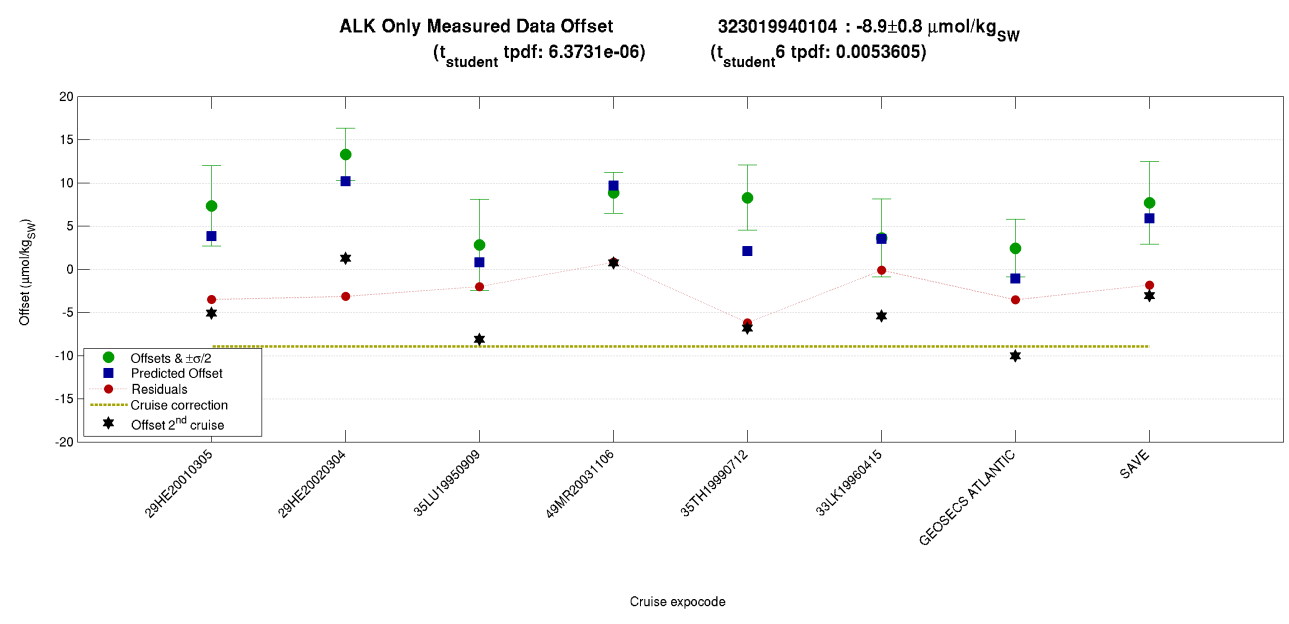

Figure 15. Cruise crossover information plot for 323019940104.

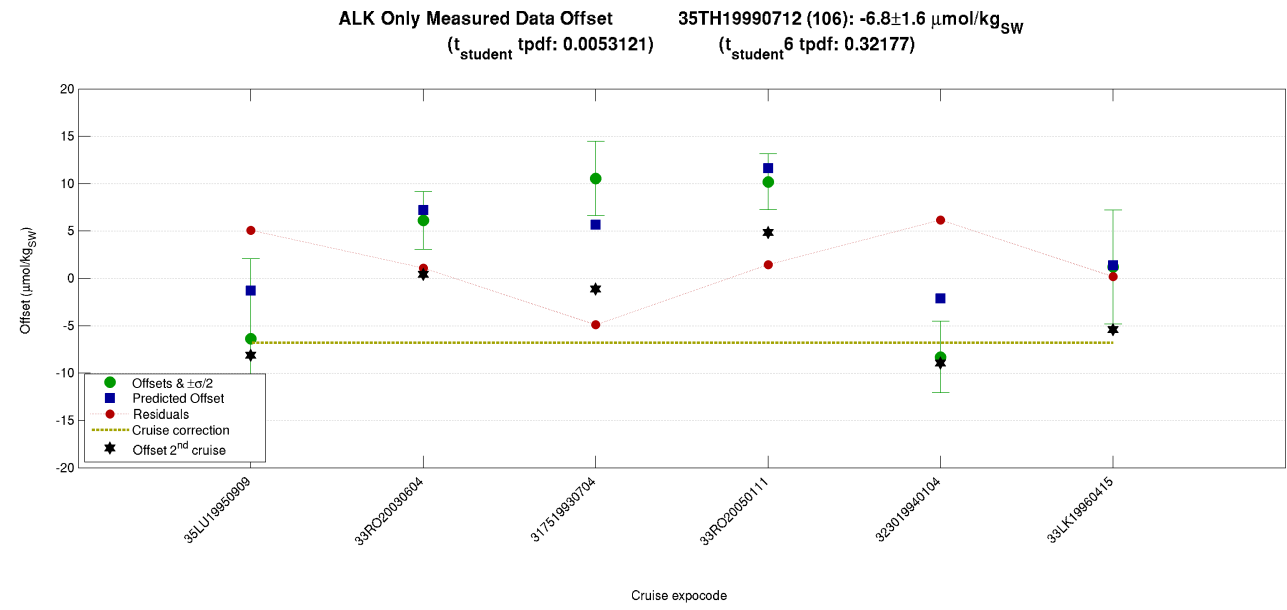

Figure 16. Cruise crossover information plot for 35TH19990712.

\subsection{Cruise 323019940104 (Fig. 15)}

This is the CITHER2 cruise, on board R/V Maurice Ewing and along the WOCE A17 section in the Western South Atlantic area from $10^{\circ} \mathrm{S}$ to $55^{\circ} \mathrm{S}$. It has 235 stations taken with a 32 place rosette system. In the cruise report, an offset for alkalinity of $-8 \mu \mathrm{mol} \mathrm{kg}{ }^{-1}$ was stated. There are eight crossovers that give a fitted correction of $-8.9 \mu \mathrm{mol} \mathrm{kg}-1$. The suggested adjustment is $-8 \mu \mathrm{mol} \mathrm{kg}^{-1}$ because it agrees with both the fitted result and the cruise report. Most of the inversion residuals fit inside $\pm 5 \mu \mathrm{mol} \mathrm{kg}$. . There are very good fits with four GLODAP cruises. Based on this evidence, an adjustment of $-8 \mu \mathrm{mol} \mathrm{kg}{ }^{-1}$ was applied to the alkalinity data.

\subsection{Cruise 35TH19990712 (106) (Fig. 16)}

This is the so called EQUALANT99 cruise, on board $\mathrm{R} / \mathrm{V}$ Thalassa in the Equatorial Atlantic area. It has 102 stations taken with a 24 place rosette system. Precision is reported as $1.7 \mu \mathrm{mol} \mathrm{kg}^{-1}$. A comparison with WOCE A15 data implies offset values as high as $12.7 \mu \mathrm{mol} \mathrm{kg}^{-1}$. There are six crossovers, giving a fitted correction of $-6.8 \mu \mathrm{mol} \mathrm{kg}{ }^{-1}$. The suggested adjustment is $-6 \mu \mathrm{mol} \mathrm{kg}-1$. All inversion residuals fit inside $\pm 6 \mu \mathrm{mol} \mathrm{kg}^{-1}$ after corrections are applied. There are very good fits with two GLODAP cruises. Based on this evidence, an adjustment of $-6 \mu \mathrm{mol} \mathrm{kg}{ }^{-1}$ was applied to the alkalinity data. 


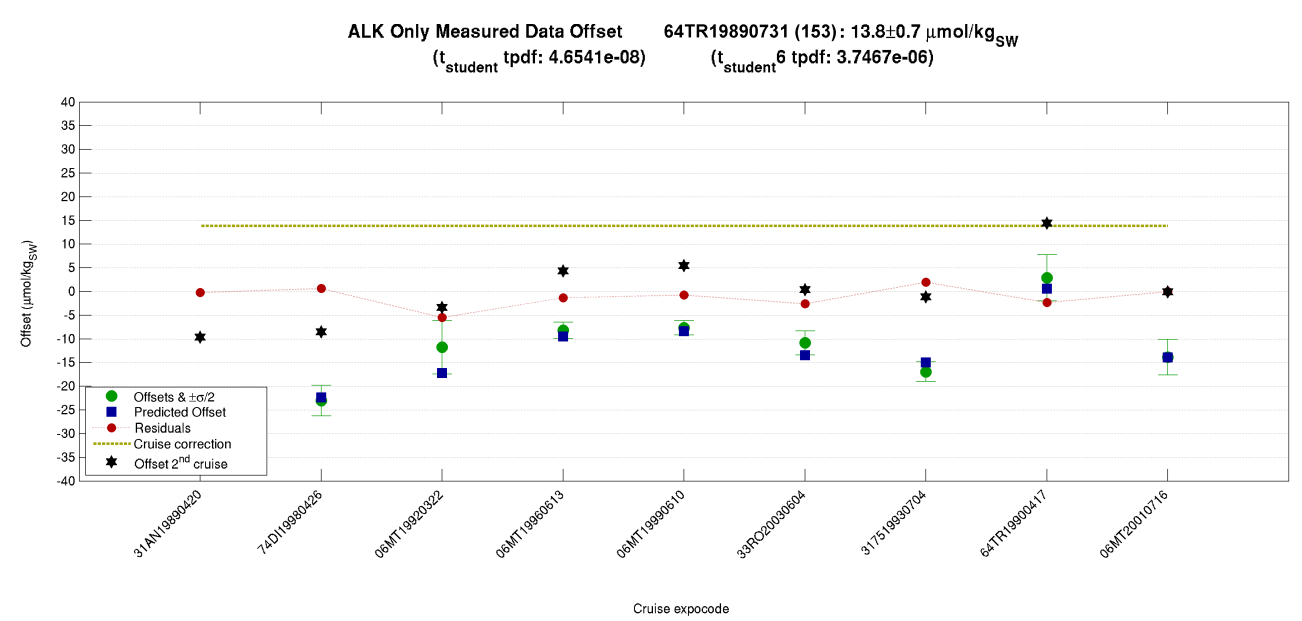

Figure 17. Cruise crossover information plot for 64TR19890731.

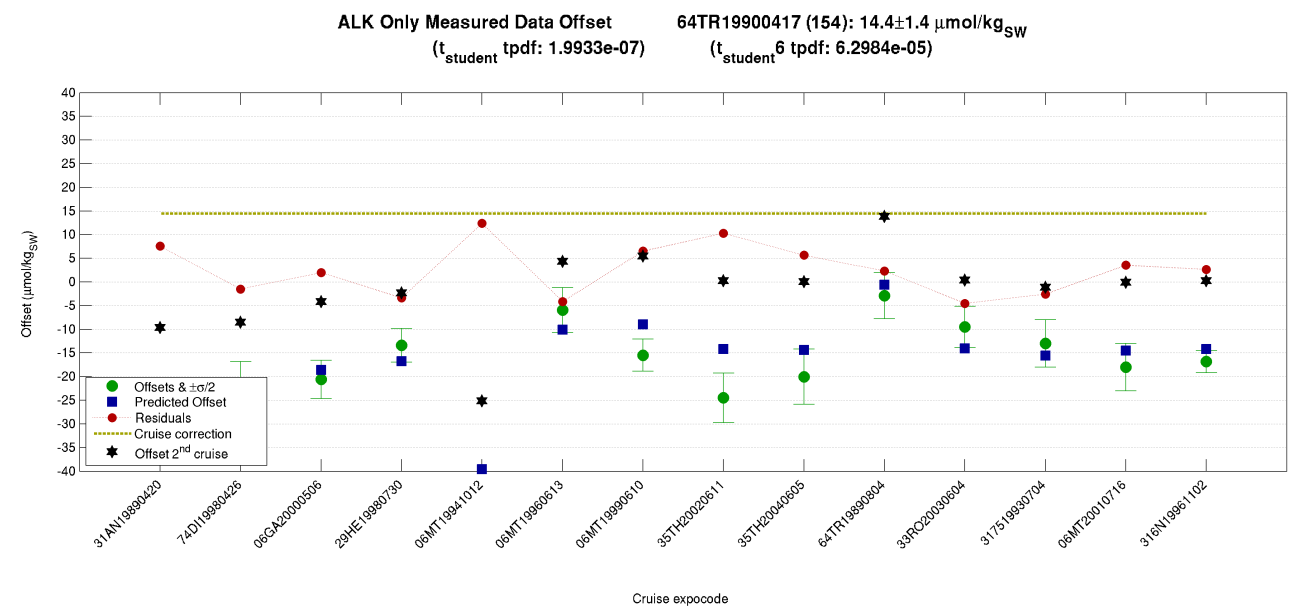

Figure 18. Cruise crossover information plot for 64TR19900417.

\subsection{Cruise 64TR19890731 (153) (Fig. 17)}

This cruise is also called 64TY8908, on board R/V Tyro along a meridional $\mathrm{A} 16 \mathrm{~N}$ section at $20^{\circ} \mathrm{W}$. The cruise has 73 stations and 12 sampling levels using a rosette system. Nine stations have been flagged 3 . There are nine crossovers giving a fitted correction of $13.8 \mu \mathrm{mol} \mathrm{kg}^{-1}$. The suggested adjustment is $14 \mu \mathrm{mol} \mathrm{kg}^{-1}$. All inversion residuals are close to zero and fit inside the $\pm 5 \mu \mathrm{mol} \mathrm{kg}^{-1}$ boundary. There are very good fits with two GLODAP cruises. Based on this evidence, an adjustment of $14 \mu \mathrm{mol} \mathrm{kg}-1$ was applied to the alkalinity data.

\subsection{Cruise 64TR19900417 (154) (Fig. 18)}

This cruise is also called 64TY9001, on board R/V Tyro along a meridional $\mathrm{A} 16 \mathrm{~N}$ section at $20^{\circ} \mathrm{W}$ from $30^{\circ} \mathrm{N}$ to $60^{\circ} \mathrm{N}$. This cruise has 23 stations with multiple casts on most of them. The method of Bradshaw et al. (1981), and calculations with constants of Goyet and Poisson (1989) were used. Values are about $20 \mu \mathrm{mol} \mathrm{kg}^{-1}$ low relative to CLIVAR A16N-2003 and have twice the scatter. There are 14 crossovers. The fitted correction is $+14.4 \mu \mathrm{mol} \mathrm{kg}{ }^{-1}$. The suggested adjustment is $+14 \mu \mathrm{mol} \mathrm{kg}{ }^{-1}$. After fitted corrections are applied, 10 inversion residuals fit inside $\pm 5 \mu \mathrm{mol} \mathrm{kg}^{-1}$. There are good fits with two GLODAP and one core cruise (06GA20000506). Based on this evidence, an adjustment of $14 \mu \mathrm{mol} \mathrm{kg}^{-1}$ was applied to the alkalinity data. 


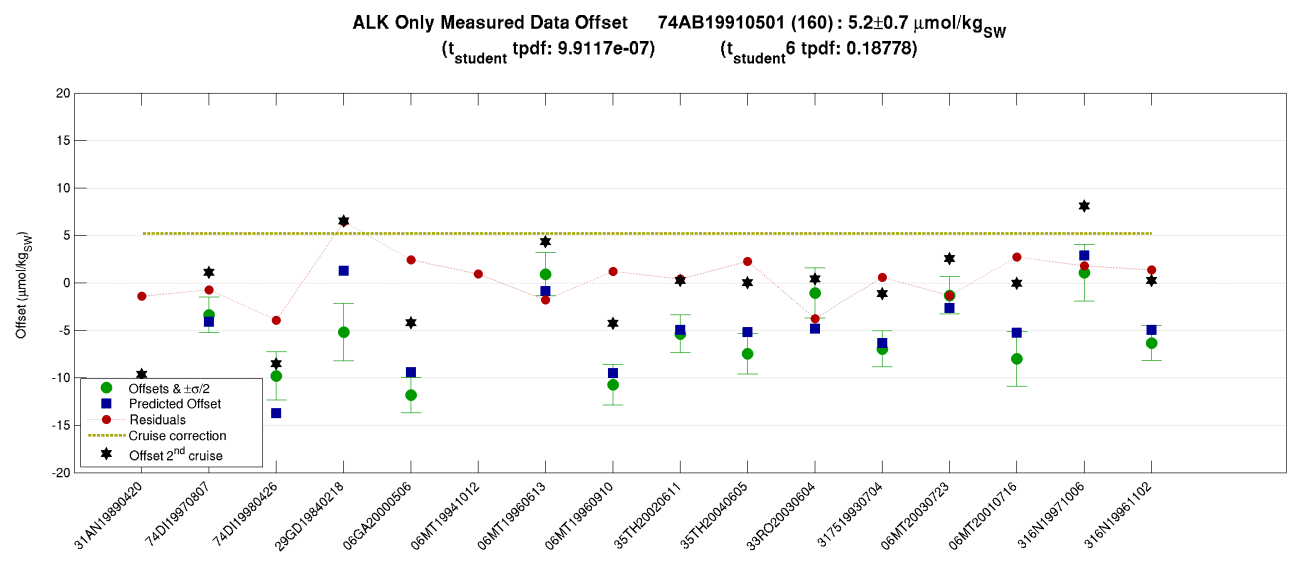

Figure 19. Cruise crossover information plot for 74AB19910501.

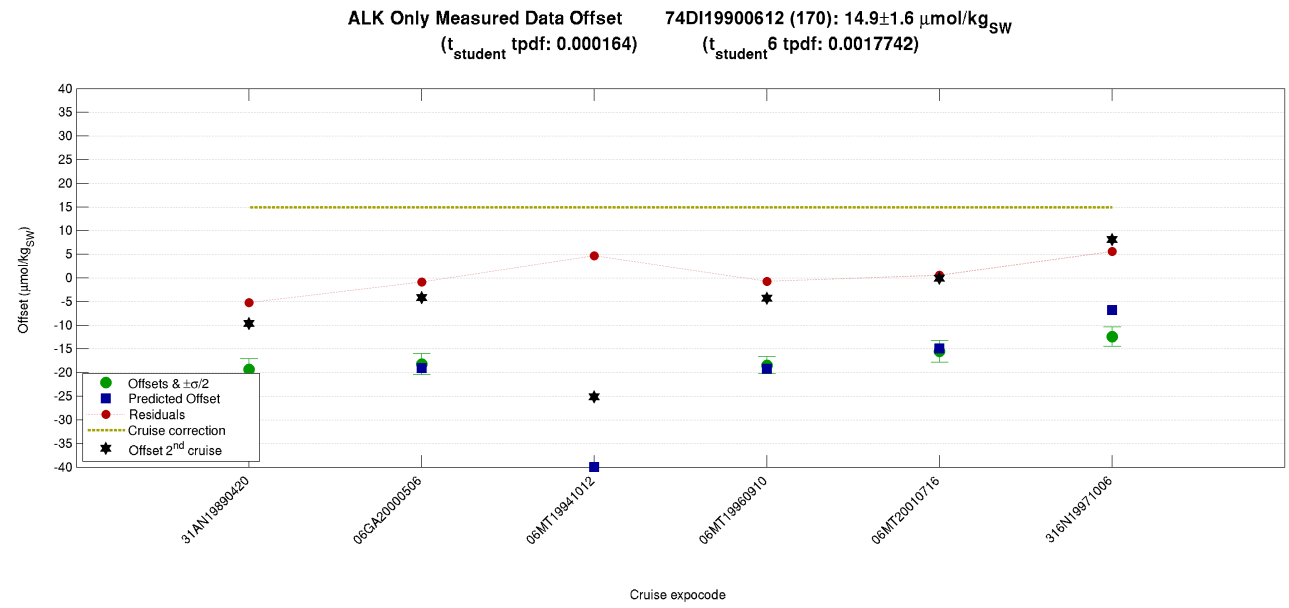

Figure 20. Cruise crossover information plot for 74DI19900612.

\subsection{Cruise 74AB19910501 (160) (Fig. 19)}

This is the so called Vivaldi expedition, on board $\mathrm{R} / \mathrm{V}$ Charles Darwin in the NE Atlantic area primarily West of Iberia. It has 614 stations, from which only 34 are deep stations. The samples were taken with a 24 place rosette system. According to the cruise report, the values are low in relation to GLODAP by about $15 \mu \mathrm{mol} \mathrm{kg}^{-1}$. Good precision is noted. Laboratory-made borax standards were used but no CRMs. There are 16 crossovers giving a fitted adjustment of $5.2 \mu \mathrm{mol} \mathrm{kg}{ }^{-1}$. The suggested adjustment is $5 \mu \mathrm{mol} \mathrm{kg}{ }^{-1}$ as a student t-test shows that the proposed correction is indistinguishable from 6 . Crossovers with six core cruises also support the proposed offset. Furthermore, GLODAP 317519930704 supports this adjustment, as very low residuals are present after the offset has been applied. Based on this evidence, an adjustment of $5 \mu \mathrm{mol} \mathrm{kg}^{-1}$ was applied to the alkalinity data.

\subsection{Cruise 74DI19900612 (170) (Fig. 20)}

This cruise is also called 74DI192, and was conducted on $\mathrm{R} / \mathrm{V}$ Discovery in the North Atlantic area from $46^{\circ} \mathrm{N}$ to $49^{\circ} \mathrm{N}$ and $17^{\circ} \mathrm{W}$ to $15^{\circ} \mathrm{W}$. This cruise has 20 stations and 12 sampling levels using a rosette system. Comparing with one GLODAP station, values are about $18 \mu \mathrm{mol} \mathrm{kg}-1$ lower. There are six crossovers giving a fitted correction of $14.9 \mu \mathrm{mol} \mathrm{kg}-1$. The inversions suggest an adjustment of $15 \mu \mathrm{mol} \mathrm{kg}^{-1}$. Inversion residuals are inside $\mathrm{a} \pm 5 \mu \mathrm{mol} \mathrm{kg} \mathrm{kg}^{-1}$ boundary after corrections are applied. Based on this evidence, an adjustment of $15 \mu \mathrm{mol} \mathrm{kg}{ }^{-1}$ was applied to the alkalinity data. 


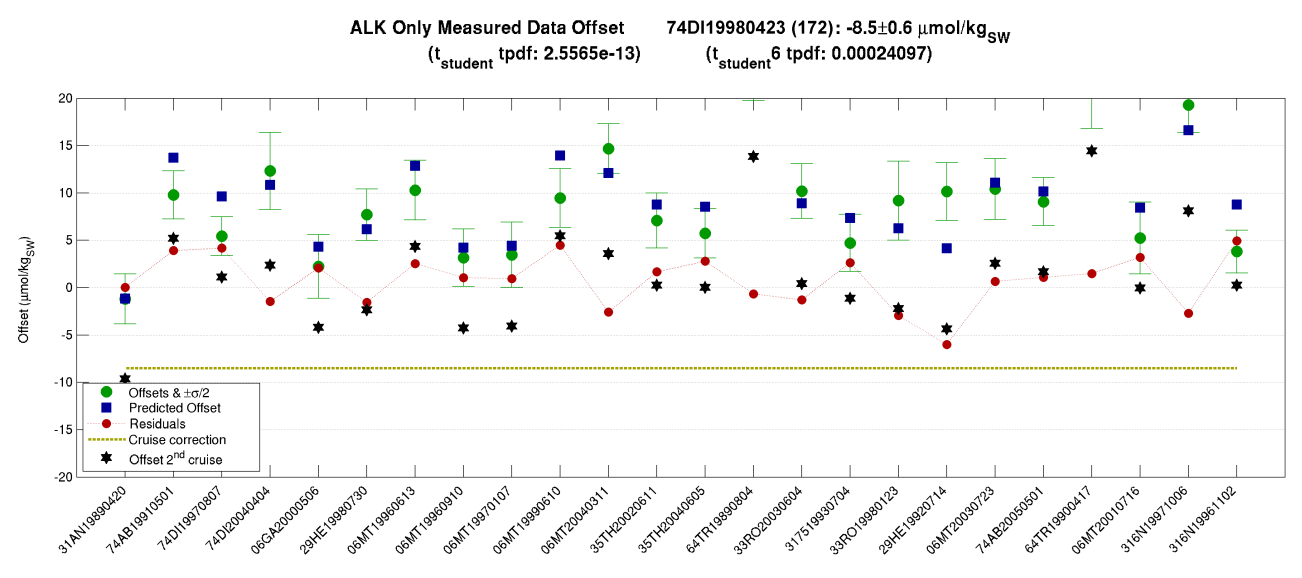

Cruise expocode

Figure 21. Cruise crossover information plot for 74DI19980423.

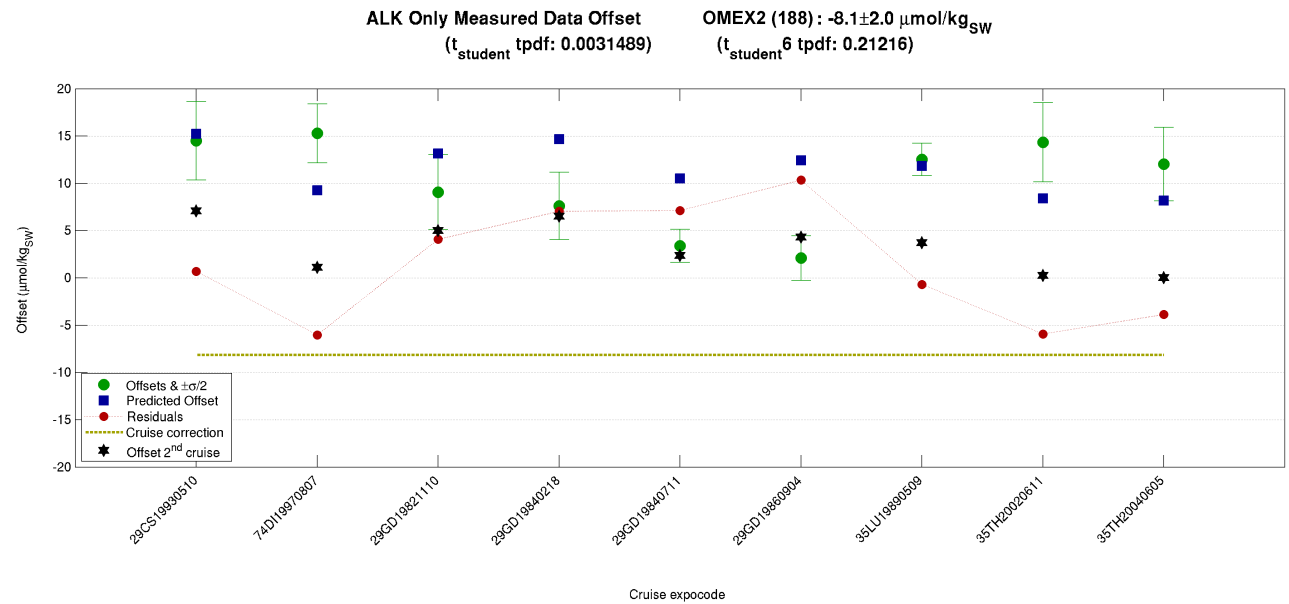

Figure 22. Cruise crossover information plot for OMEX2.

\subsection{Cruise 74DI19980423 (172) (Fig. 21)}

This is the 74DI233 cruise, also called Chaos, conducted on $\mathrm{R} / \mathrm{V}$ Discovery, performing a meridional section along $20^{\circ} \mathrm{W}$ from $20^{\circ} \mathrm{N}$ to $60^{\circ} \mathrm{N}$. It has 44 full depth stations taken with a 24 place rosette system. Data is generally good, with a few data high relative to neighbours and GLODAP. CRMs were used. There are 24 crossovers giving a fitted correction of $-8.5 \mu \mathrm{mol} \mathrm{kg}{ }^{-1}$. The suggested adjustment is $-9 \mu \mathrm{mol} \mathrm{kg}-1$. Most of the residuals fit very close to zero and keep inside $\pm 5 \mu \mathrm{mol} \mathrm{kg}^{-1}$ after corrections are applied. There are very good fits with core and GLODAP cruises. Based on this evidence, an adjustment of $-9 \mu \mathrm{mol} \mathrm{kg}^{-1}$ was applied to the alkalinity data.

\subsection{Cruise OMEX2 (188) (Fig. 22)}

This is also called OMEX2 Project Time Series. Rather than a single cruise, it is a compilation of 12 cruises performed on board R/Vs Belgica, Charles Darwin and Meteor on the NW Iberian margin. There are nine crossovers giving a fitted correction of $-8.1 \mu \mathrm{mol} \mathrm{kg}{ }^{-1}$. The suggested adjustment is $-8 \mu \mathrm{mol} \mathrm{kg}^{-1}$. With one exception, all inversion residuals fit inside $\pm 6 \mu \mathrm{mol} \mathrm{kg}{ }^{-1}$. There are three crossovers with core cruises that appear to suggest an even larger offset. Based on this evidence, an adjustment of $-8 \mu \mathrm{mol} \mathrm{kg}^{-1}$ was applied to the alkalinity data. 

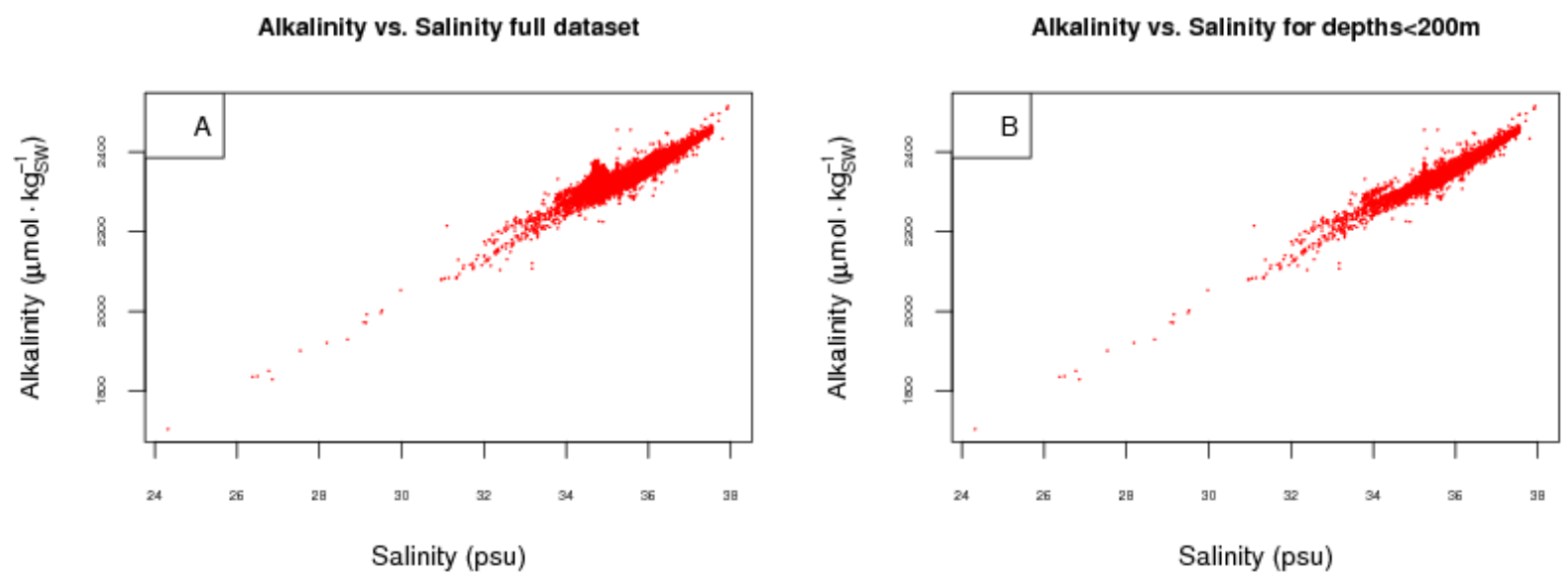

Figure 23. Alkalinity data in CARINA final database versus salinity for: (A) data deeper than $200 \mathrm{~m}$ (B) depths $<200 \mathrm{~m}$.

\section{Data quality evaluation}

As derived from its definition, the salt content of seawater is a determining factor on the $A_{T}$. For this reason, salinity is a good parameter to explain some of the $A_{T}$ variability. In Fig. 23a, alkalinity is shown against salinity for the full CARINA-ATL dataset. As expected, the parameters correlate well, giving a $R^{2}$ regression coefficient of 0.77 . As near surface formation of water masses is the main process that affects $A_{T}$ variability, Fig. 23b, represents the variation of $A_{T}$ versus salinity for the subset of surface waters (depth $<200 \mathrm{~m}$ ). The correlation for this data set is higher than in Fig. 23a, giving a $R^{2}$ of 0.94 due to the fact that most of the variability in both salt and alkalinity occurs in the upper few hundred meters. This enforces the idea of the interdependence of both parameters.

To make an overall evaluation of the dataset quality, additional variables that can affect the natural variability of the alkalinity were introduced in the regression. Thus, a MultiLinear Regression (MLR) was performed with potential temperature $(\theta)$, salinity, latitude, apparent oxygen utilisation (AOU), nitrate, phosphate and silicate in order to remove as much natural variability as possible. All of these parameters were included knowing that interdependence exists between many of them. However, the goal here is not to generate a statistical model for alkalinity, but rather a way of getting residuals with natural variability removed to a large extent (about 90\%), so that they can be used to test the data quality. This analysis method facilitates a better assessment of scatter and biases in the alkalinity dataset, and even to test the applied adjustments. The MLR procedure can transmit the measurement error of the explanatory variables to the residuals despite being quite lower than the alkalinity error.

In order to improve the quality of the evaluation, the MLR analysis was applied in four density layers, with density at $1000 \mathrm{db}\left(\sigma_{1}\right)$ being used to divide the ocean. The upper thermocline was set by $\sigma_{1}<32.25 \mathrm{~kg} \mathrm{~m}^{-3}$; intermediate waters (depths from about 1000 to $2000 \mathrm{~m}$ ) were defined by second layer $\left(32.25<=\sigma_{1}<32.39 \mathrm{~kg} \mathrm{~m}^{-3}\right)$; water depths between $\sim 2000$ to $3000 \mathrm{~m}$ were defined by $32.39<=\sigma_{1}<32.53 \mathrm{~kg} \mathrm{~m}^{-3}$ - corresponding to North Atlantic Deep Waters (NADW); and finally, the fourth layer refers to bottom waters, where the presence of Antarctic Bottom Waters (AABW) dominates. This last layer is set by $\sigma_{1}>32.53 \mathrm{~kg} \mathrm{~m}^{-3}$. The surface layer with depths $<200 \mathrm{~m}$ was removed from this evaluation.

Using this analysis, alkalinity residuals were calculated by the following Eq. (2):

$$
\begin{aligned}
& A_{T \_\mathrm{MLR}}=\sum_{i=1}^{8} a_{i} \cdot X_{i} \\
& A_{T \_ \text {residuals }}=A_{T \text { _measured }}-A_{T \_\mathrm{MLR}}
\end{aligned}
$$

where $X_{i}$ stand for $\theta$, salinity, latitude, AOU, nitrate, phosphate, silicate, and a constant term. This procedure was done with the CARINA-ATL corrected database, and also for the database without any alkalinity adjustments applied.

The alkalinity residuals for each density layer are shown in Fig. 24. This shows a box plot of alkalinity residuals cruise data for each cruise. The box/whiskers represent the typical five number summary (minimum, 25th percentile, median, 75 th percentile and maximum), the width of individual boxes corresponds to the number of samples for that cruise, and the numbers on the $\mathrm{x}$-axis are the CARINA cruise IDs as referenced in Table 1.

The best fit $\left(R^{2}=0.95\right)$ is obtained for the shallower waters, with a mean standard deviation of $6.2 \mu \mathrm{mol} \mathrm{kg}^{-1}$. The other layers have a slightly lower mean standard deviation (5.4, $5.9 \mu \mathrm{mol} \mathrm{kg}^{-1}$ respectively), except for the bottom layer with $6.5 \mu \mathrm{mol} \mathrm{kg}{ }^{-1}$. The median of mean standard deviations for all cruises is $4.1 \mu \mathrm{mol} \mathrm{kg}{ }^{-1}$ units for each of three deepest density layers. The lower panel in the figure stands for the joined alkalinity residuals of the four density layers.

As can be seen, alkalinity residuals are lower when using the corrected database, in comparison with the uncorrected 


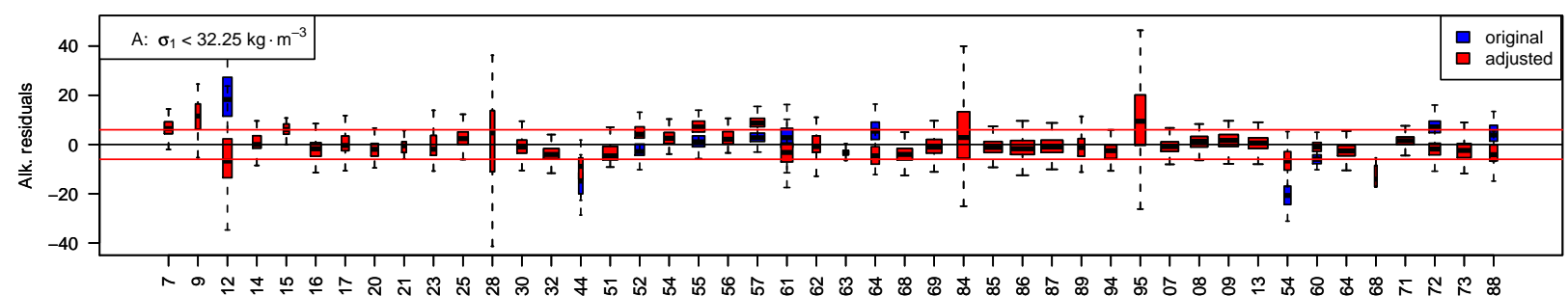

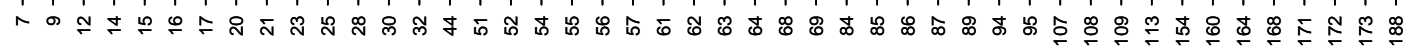

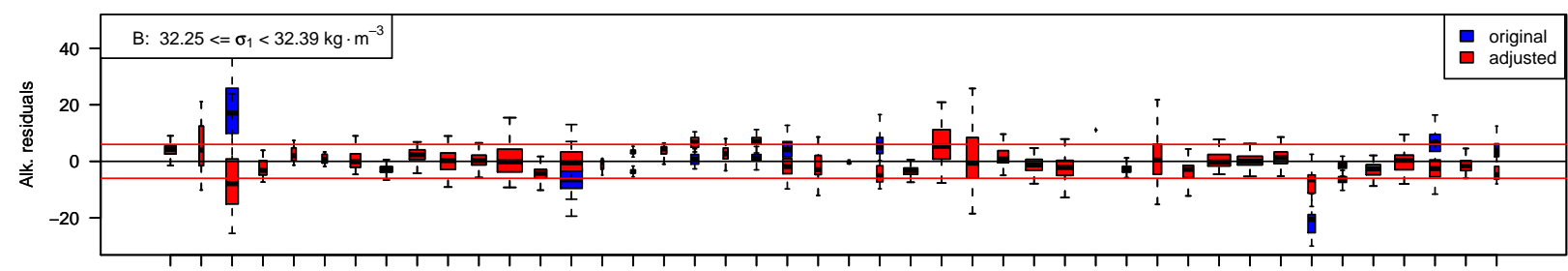

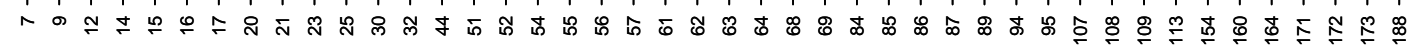
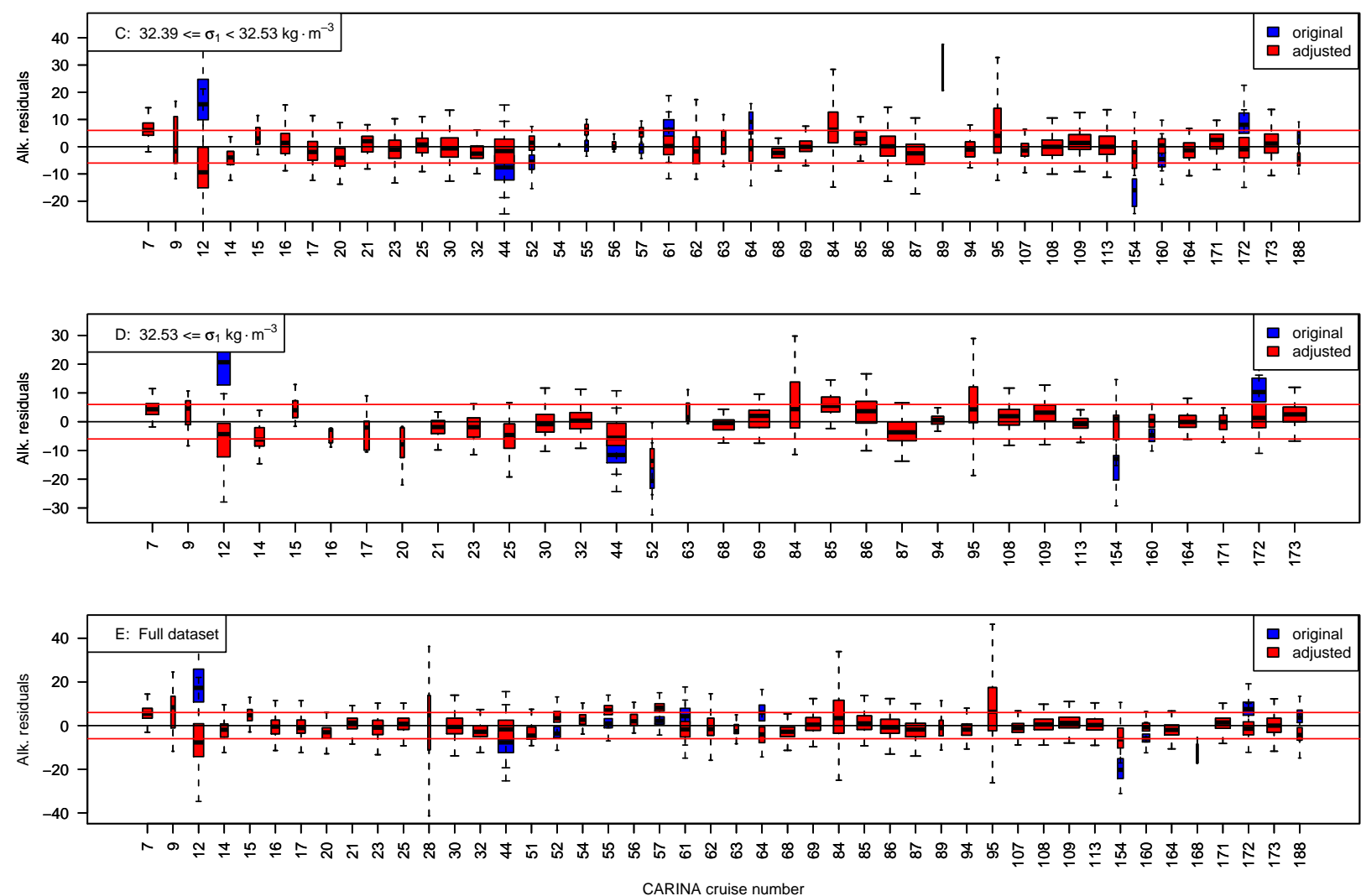

Figure 24. Alkalinity residuals obtained from CARINA-ATL dataset by applying an MLR for alkalinity data against Theta, Salinity, Latitude, AOU, Nitrate, Phosphate and Silicate. (A to D) are CARINA-ATL subsets for the indicated $\sigma_{1}$ interval, and (E) is the join for the full dataset. Blue values are residuals with the original unadjusted alkalinity values, and Red values are the final adjusted alkalinity values. Red lines are the $\pm 6 \mu \mathrm{mol} \mathrm{kg}-1$ of alkalinity used as lower limit for adjustments in the crossover exercise.

original ones. Most but not all of the cruises have the alkalinity residuals median inside of the $\pm 6 \mu \mathrm{mol} \mathrm{kg}^{-1}$ boundary, showing that in addition to the alkalinity measurement errors, there are two other sources that increase the variability of the alkalinity residuals: firstly, the MLR is not able to ex- plain all of the naturally observed variability of alkalinity; and secondly, the predictor parameters have their own inherent measurement errors. 
Acknowledgements. This work has been performed and funded as part of the EU project CarboOcean (Project 511176). Additional support from the International Ocean Carbon Coordination Project IOCCP (Maria Hood) and the Hanse Institute for Advanced Study (HWK Delmenhorst, Germany) are gratefully acknowledged. Additional support provided as follows: for A. Velo, F. F. Perez, PGIDIT05OXIC40203PM Xunta de Galicia and CTM200627116E/MAR MEC; P. J. Brown, Award NER/S/A/2004/12255; and R. M. Key, NOAA grant NA08OAR4320752 and NA08OAR4310820. We want also to thank the hard work and dedication of analysts and investigators that collect the data at the sea; without them, this work would not be possible. We gratefully acknowledge also those who have contributed their data to the CARINA project.

Edited by: M. Hoppema

\section{References}

Bradshaw, A., Brewer, P., Shafer, D., and Williams, R.: Measurements of total carbon dioxide and alkalinity by potentiometric titration in the geosecs program, Earth Planet. Sci. Lett, 55, 99115,1981

Dickson, A.: An exact definition of total alkalinity and a procedure for the estimation of alkalinity and total inorganic carbon from titration data, Deep-Sea Res., 28, 609-623, 1981.

Dickson, A. G., Sabine, C. L., and Christian, J. R.: Guide to best practices for ocean $\mathrm{CO}_{2}$ measurements, PICES Special Publication, 3, 191 pp., 2007.

Feely, R. A., Sabine, C. L., Lee, K., Millero, F. J., Lamb, M. F., Greeley, D., Bullister, J. L., Key, R. M., Peng, T. H., Kozyr, A., Ono, T., and Wong, C. S.: In situ calcium carbonate dissolution in the pacific ocean, Global Biogeochem. Cy., 16, 1144, doi:10.1029/2002GB001866, 2002.

Goyet, C. and Poisson, A.: New determination of carbonic acid dissociation constants in seawater as a function of temperature and salinity, Deep-Sea Res., 36, 1635-1654, 1989.

Hoppema, M., Velo, A., van Heuven, S., Tanhu, T., Key, R. M., Lin, X., Bakker, D. C. E., Perez, F. F., Ríos, A. F., Lo Monaco, C., Sabine, C. L., Álvarez, M., and Bellerby, R. G. J.: Consistency of cruise data of the CARINA database in the Atlantic sector of the Southern Ocean, Earth Syst. Sci. Data Discuss., 2, 331-365, 2009 ,

http://www.earth-syst-sci-data-discuss.net/2/331/2009/.

Jutterström, S., Anderson, L. G., Bates, N. R., Bellerby, R., Johannessen, T., Jones, E. P., Key, R. M., Lin, X., Olsen, A., and Omar, A. M.: Arctic Ocean data in CARINA, Earth Syst. Sci. Data Discuss., 2, 281-308, 2009,

http://www.earth-syst-sci-data-discuss.net/2/281/2009/.
Key, R. M., Kozyr, A., Sabine, C. L., Lee, K., Wanninkhof, R., Bullister, J. L., Feely, R. A., Millero, F. J., Mordy, C., and Peng, T. H.: A global ocean carbon climatology: Results from global data analysis project (glodap), Global Biogeochem. Cy. 18, GB4031, doi:10.1029/2004GB002247, 2004.

Key, R. M., Tanhua, T., Olsen, A., Hoppema, M., Jutterström, S., Schirnick, C., van Heuven, S., Kozyr, A., Lin, X., Velo, A., Wallace, D. W. R., and Mintrop, L.: The CARINA data synthesis project: Introduction and overview, Earth Syst. Sci. Data Discuss., in press, 2009.

Lo Monaco, C., Álvarez, M., Key, R. M., Lin, X., Tanhua, T., Tilbrook, B., Bakker, D. C. E., van Heuven, S., Hoppema, M., Metzl, N., Ríos, A. F., Sabine, C. L., and Velo, A.: Assessing the internal consistency of the CARINA database in the Indian sector of the Southern Ocean, Earth Syst. Sci. Data Discuss., 2, 367-419, 2009,

http://www.earth-syst-sci-data-discuss.net/2/367/2009/.

Mintrop, L., Pérez, F., González-Dávila, M., Santana-Casiano, J., and Körtzinger, A.: Alkalinity determination by potentiometry: Intercalibration using three different methods, Ciencias Marinas, 26, 23-37, 2000.

Olsen, A.: Nordic Seas total alkalinity data in CARINA, Earth Syst. Sci. Data Discuss., 2, 309-330, 2009, http://www.earth-syst-sci-data-discuss.net/2/309/2009/.

Sabine, C., Key, R., Kozyr, A., Feely, R., Wanninkhof, R., Millero, F., Peng, T., Bullister, J., and Lee, K.: Global ocean data analysis project (glodap): Results and data, ndp-083, 110 pp., Carbon Dioxide Inf. Anal. Cent., Oak Ridge Natl. Lab., Oak Ridge, Tenn., 2005.

Sabine, C. L., Hoppema, M., Key, R. M., Tilbrook, B., van Heuven, S., Lo Monaco, C., Metzl, N., Ishii, M., Murata, A., and Musielewicz, S.: Assessing the internal consistency of the CARINA data base in the Pacific sector of the Southern Ocean, Earth Syst. Sci. Data Discuss., 2, 555-578, 2009, http://www.earth-syst-sci-data-discuss.net/2/555/2009/.

Tanhua, T., Steinfeldt, R., Key, R. M., Brown, P., Gruber, N., Wanninkhof, R., Perez, F., Körtzinger, A., Velo, A., Schuster, U., van Heuven, S., Bullister, J. L., Stendardo, I., Hoppema, M., Olsen, A., Kozyr, A., Pierrot, D., Schirnick, C., and Wallace, D. W. R.: Atlantic Ocean CARINA data: overview and salinity adjustments, Earth Syst. Sci. Data Discuss., 2, 241-280, 2009a, http://www.earth-syst-sci-data-discuss.net/2/241/2009/.

Tanhua, T., van Heuven, S., Key, R. M., Velo, A., Olsen, A., and Schirnick, C.: Quality control procedures and methods of the CARINA database, Earth Syst. Sci. Data Discuss., 2, 205-240, 2009b, http://www.earth-syst-sci-data-discuss.net/2/205/2009/.

Wanninkhof, R., Tsung-Hung, P., Huss, B., Sabine, C. L., and Lee, K.: Comparison of inorganic carbon system parameters measured in the atlantic ocean from 1990 to 1998 and recommended adjustments, Carbon Dioxide Information Analysis Center, Oak Ridge National Laboratory, ORNL/CDIAC-140, 2003. 